\title{
Life Cycle Costs and Life Cycle Assessment for the Harvesting, Conversion, and the Use of Switchgrass to Produce Electricity
}

\author{
Nuttapol Lerkkasemsan and Luke E. K. Achenie \\ Department of Chemical Engineering, Virginia Polytechnic Institute and State University, Blacksburg, VA 24061-0002, USA \\ Correspondence should be addressed to Nuttapol Lerkkasemsan; nuttapol@vt.edu
}

Received 2 May 2013; Revised 16 July 2013; Accepted 21 July 2013

Academic Editor: Antonia Pérez de los Ríos

Copyright (C) 2013 N. Lerkkasemsan and L. E. K. Achenie. This is an open access article distributed under the Creative Commons Attribution License, which permits unrestricted use, distribution, and reproduction in any medium, provided the original work is properly cited.

\begin{abstract}
This paper considers both LCA and LCC of the pyrolysis of switchgrass to use as an energy source in a conventional power plant. The process consists of cultivation, harvesting, transportation, storage, pyrolysis, transportation, and power generation. Here pyrolysis oil is converted to electric power through cocombustion in conventional fossil fuel power plants. Several scenarios are conducted to determine the effect of selected design variables on the production of pyrolysis oil and type of conventional power plants. The set of design variables consist of land fraction, land shape, the distance needed to transport switchgrass to the pyrolysis plant, the distance needed to transport pyrolysis oil to electric generation plant, and the pyrolysis plant capacity. Using an average agriculture land fraction of the United States at 0.4, the estimated cost of electricity from pyrolysis of 5000 tons of switchgrass is the lowest at $\$ 0.12$ per kwh. Using natural gas turbine power plant for electricity generation, the price of electricity can go as low as $7.70 \mathrm{cent} / \mathrm{kwh}$. The main advantage in using a pyrolysis plant is the negative GHG emission from the process which can define that the process is environmentally friendly.
\end{abstract}

\section{Introduction}

Our dependence on fossil fuel has increased over the past century due to increasing energy consumption. The U.S. Department of Energy [1] stated that transportation energy demand is increasing at an annual rate of 0.2 percent from year 2010 to 2035 . Total electricity consumption is also increasing at an annual rate of 0.8 percent from 3879 billion kilowatt-hours in 2010 to 4775 billion kilowatt-hours in 2035 . On the other hand, the world oil reservoir is decreasing. From BP's estimates [2], world oil production has already reached its maximum and is expected to drop. At the present production rate, the world oil reservoir will last for forty-one years. Renewable energy such as biooil will be an alternative source to make up the reduction of oil production rate. Faaij [3] reported that fossil fuel dominated the world's energy uses, supplying $80 \%$ of the total energy requirement. However, $10-15 \%$ of this demand could be covered by biomass resource. Biomass is an important energy resource for developing countries accounting for $50-90 \%$ of their total energy requirement. Advantages of biomass energy include potential to reduce GHG emissions, substitution for depleting global crude oil reservoir, potential impacts on waste management, and the conversion of waste resources into clean energy. Waste resources include natural forests wood, forestry residues, agricultural residues, industrial wastes, food processing wastes, and municipal solid wastes.

With the increasing concern of greenhouse gas from petroleum sources, searching for clean and environmental friendly energy resource has become more important [4]. Richard et al. [5] reported perturbation of greenhouse gas such as carbon dioxide $\left(\mathrm{CO}_{2}\right)$, methane $\left(\mathrm{CH}_{4}\right)$, and nitrous oxide $\left(\mathrm{N}_{2} \mathrm{O}\right)$, which have been created by human activity such as utilization of fossil fuel and landuse change to the global climate. A measurement of carbon dioxide at Mauna Loa Observatory showed that the rate of release of carbon 
dioxide into the atmosphere has increased from less than 1 ppm per year in 1970 to more than 2 ppm per year in 2009. It is expected that the rate will increase exponentially [6].

Biooil is one of the promising clean energy substitutes since it can be replaced or mixed with fossil fuel to use in a conventional technology engine. In this study, the biooil is produced and used in conventional power plant. Hammons [7] reported a study of greenhouse gas emissions from electric power plant in Europe. Carbon dioxide from fossil fuel combustion in a power plant is more than one-third of the total carbon dioxide emission and the fraction is increasing. From AEO 2012 [8], carbon dioxide produced from electricity generation is increasing at a rate of 0.2 percent per year until 4.9 percent from year 2010 to 2035. Brammer et al. [9] reported on the use of biooil in heat, power, or combined heat and power (CHP) in 14 European countries. They reported that heat application is the most economically competitive followed by CHP application. Fan et al. [10] conducted life cycle assessment of electricity generation using fast pyrolysis biooil from short rotation forestry willow, poplar, collection of hard wood residue from existing forestry operations, and wasted wood from a sawmill available at the site of pyrolysis plant. They reported that using fast pyrolysis oil in power plants could save GHG emission about 77\%-99\% depending on the biomass feedstock and type of power plant. Solantausta et al. [11] reported the use of fast pyrolysis oil in diesel engine in power plant. The modification in diesel engine by adding injection system which help ignition of the fuel consistence is necessary. Arbon [12] reported on the use of biomass in power generation. He discussed the use of pyrolysis and gasification product in conventional combustion system such as steam turbine, boiler, and reciprocating engine. However, the development in technology is needed to reduce high capital cost of pyrolysis process. Chiaramonti et al. [13] reported on the use of pyrolysis in diesel engine, gas turbine, and natural gas/steam power plant.

Advantages of using fast pyrolysis oil as fuel are that it is easy to store and transport; it has a higher energy density than gasification fuel gases; it can be distilled and replaced by light fuel oil, and it can be used in conventional fossil fuel power plant [13]. Arbogast et al. [14] reported the economic study of pyrolysis oil. The authors concluded that waste biomass such as logging residues is the lowest cost material for pyrolysis oil. However, there is a supply limitation for waste biomass material. On the other hand, growing energy crop is more expensive. However, with more concentrated production of energy crop, logistic cost can be reduced. Growing energy crop provides a more stable energy source thus reducing the limitation of pyrolysis oil production. Boateng et al. [15] stated that pyrolysis oil from switchgrass as an energy crop has a yield greater than $60 \%$. The energy conversion efficiencies of switchgrass are ranked between $52 \%$ and $81 \%$. This paper focuses on life cycle assessment and life cycle cost of using switchgrass as an energy crop from field to power plant.

The rest of the paper is organized as follows. Section 2 is the background for LCA (life cycle assessment), LCC (life cycle cost), and switchgrass. Section 3 describes the methodology in this work. Section 4 presents and discusses
TABLE 1: Biomass yield of switchgrass cultivars grown in southern Iowa from 1998 to 2001 [21].

\begin{tabular}{lc}
\hline Varieties & Yield $\left(\mathrm{Mg} \mathrm{ha}^{-1}\right)$ \\
\hline Upland & 7.9 \\
Trailblazer & 8.3 \\
Blackwell & 9.3 \\
Cave-in-Rock & 7.3 \\
Pathfinder & 7.8 \\
Caddo & \\
Lowland & 12.1 \\
Alamo & 13.1 \\
Kanlow & \\
\hline
\end{tabular}

the results. The final section is the set of conclusions for this work.

\section{Background}

2.1. Switchgrass. Switchgrass (Panicum virgatum L.) is a perennial grass native to Central and North America. It is a promising bioenergy source for the following reasons: long life (more than 10 years), high productivity, adaptability, and high potential of integration into conventional agricultural operation. There is a significant opportunity for using switchgrass in ethanol production and also combustion fuel source for power production due to its high cellulosic content. Switchgrass can be grown in many different regions including marginal land areas due to its highly adaptability and persistence. Moreover switchgrass is tolerant to cold weather and disease [16-19].

There are many environmental benefits from growing switchgrass such as increasing soil quality, reduced losses of soil nutrients, and recycling nutrients from municipal and agricultural wastes, soil carbon sequestration, and mitigating greenhouse gas emissions. There are 14 million ha of Conservation Reserve Program (CRP) lands, which were created by the USA Food Security Act of 1985, in order to remove land from crop production and place a long-term resourceconserving vegetation cover to prevent soil erosion, improve water quality, and enhance wildlife habitat. These lands have the potential to be used as areas for biomass production $[19,20]$.

Switchgrass can be separated into two categories, namely, upland and lowland types. The upland types are suited to drier soils and are better in semiarid climates. On the other hand, the lowland types grow better in heavier soils and require more water. However, the lowland types have a higher dry mass production than the upland type. The upland types include Trailblazer, Blackwell, Cave-in-Rock, Pathfinder, and Caddo. Alamo and Kanlow are the lowland types [16].

Table 1 shows the yield of several switchgrass cultivars grown in southern Iowa. Lemus et al. [21] state that the mean yield of 20 switchgrass cultivars grown in southern Iowa and harvested in autumn 1998 through 2001 was $9.0 \mathrm{Mg} \mathrm{ha}^{-1}$. Fike et al. [22] reported that because of the lowland switchgrass 
greater productivity, they appeared better suited to biomass production in the upper southeastern USA. For the upland switchgrass, two cuts per year may be benefit dependent on production cost and feed stock quality. On the other hand, for the lowland switchgrass, two harvests per year may be less advantage for the biomass yield.

2.2. LCA. The international scientific society of environmental chemists (SETAC) [23] defines LCA as "a process to evaluate the environmental burdens associated with a product, process, or activity by identifying and quantifying energy and materials used and wastes released to the environment." The LCA frame work was developed by the International Organization for Standardization in ISO14000 series: ISO14000 on principle and frame work, ISO14041 on goal and scope definition and inventory analysis, ISO14042 on life cycle impact assessment, and ISO14043 on life cycle interpretation [24]. LCA focuses only on the environmental impacts from the production system; that is, economic and social aspects are not considered [25]. LCA of biomass in this case is applied to switchgrass: from cradle which is the cultivation of switchgrass to grave, which is electricity from power plant.

2.3. LCC. Renewable energy in the form of biooil from pyrolysis of biomass (such as switchgrass) can only exist without government subsidies when the production cost is lower or equal to that of fossil fuel energy. Therefore, in this work, a total economic analysis is necessary in order to evaluate the economic viability. Ravemark [26] defines LCC as the sum of costs (present values of investment, capital, installation, energy, operating, maintenance, and disposal) over the life-time of the project, product, or measure. Barringer [27] indicated that life cycle costs (LCC) were cradle to grave costs summarized as an economics model of evaluating alternatives for equipment and projects. Kawauchi and Rausand [28] stated that the main purpose of doing life cycle cost analysis was to find the total cost of production throughout its life cycle, which included research and development, construction, operation and maintenance, and disposal. LCC assesses the ability of using the switchgrass in pyrolysis process to create an alternative energy source which will finally be used in power plant to create electricity.

\section{Methodology}

In this work, we study LCC and LCA for the harvesting, conversion, and the use of switchgrass to produce electricity. The model system is defined in Figure 1.

In Figure 1, the process begins with the cultivation and harvesting in switchgrass farming. Subsequently, all the switchgrass is transported to storage. In the next step, switchgrass is transported to the pyrolysis plant to be converted to pyrolysis oil. Next, the pyrolysis oil is transported to the power plant for electricity generation. In this work zero net carbon emission is assumed. All of the GHG emission created at this stage is adsorbed and used in the photosynthesis of switchgrass in switchgrass field.

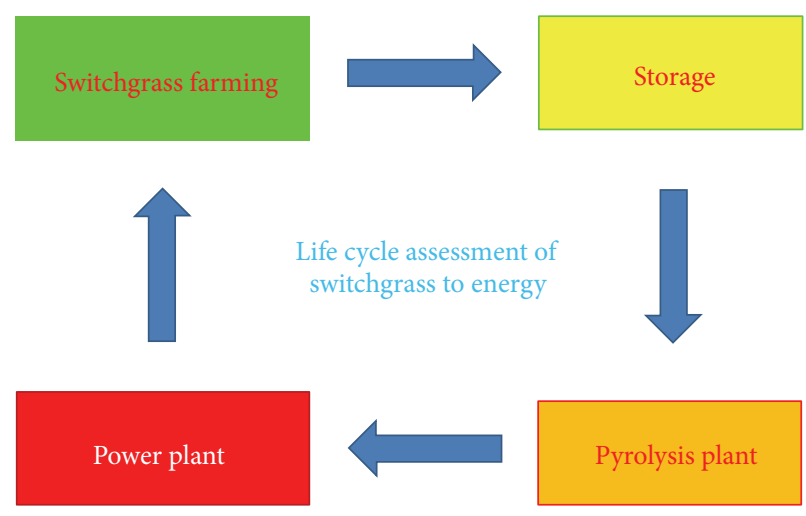

FIGURE 1: Life cycle assessment of switchgrass to energy.

LCA Model. Mass balances are employed as follows.

(1) Total emission for LCA model = (total emission from switchgrass field) + (total emission from transportation of switchgrass) + (total emission from storage process $)+$ (total emission from pyrolysis plant $)+$ (total emission from transport pyrolysis oil) + (total emission from power plant).

(2) Total emission from switchgrass field $=$ (total emission from fuel used in the field) + (total emission from fertilizer and herbicide).

(3) Total emission from transportation of switchgrass = (total emission of fuel used in transportation).

(4) Total emission from storage process $=($ total emission of fuel used in the storage system) + (total emission from the mass loss during keeping).

(5) Total emission from transportation of pyrolysis oil = (total emission of fuel used in transportation).

LCC Model. The total cost of the whole process is broken down as follows.

(6) Total cost for LCC model = (total cost from switchgrass field ) + (total cost of transportation of switchgrass $)+($ total cost from storage + total cost from pyrolysis process) + (total cost from transportation of pyrolysis oil) + (total cost from power plant).

(7) Total cost from switchgrass field $=$ (total cost of machinery) + (total cost of fuel) + (total cost of fertilizer and herbicide) + (loan interest).

(8) Total cost of transportation of switchgrass $=$ (total cost of fuel and labor).

(9) Total cost from storage $=$ (total cost of construction of storage) + (total cost of fuel and labor) + (total cost of switchgrass lost during storage).

(10) Total cost from pyrolysis process $=($ total cost of establishing pyrolysis plant) + (operating cost) + (switchgrass cost $)+($ maintenance cost $)+($ loan interest).

(11) Total cost of transportation of pyrolysis oil $=$ (total fuel cost and labor). 
(12) Total cost from power plant $=($ capital cost $)+($ operation cost $)+$ (maintenance cost).

We employed a Dell computer workstation with Intel(R) Xeon(R) CPU E5405 $2.00 \mathrm{GHz}$ and the Matlab software environment [29] to perform the calculations.

\subsection{Cost of Establishing, Reseeding, and Producing Switchgrass.} Table 2 shows the estimated costs of establishing the switchgrass and GHG while Table 3 shows the estimated reseeding costs per ha and GHG. Table 4 shows the estimated yearly production costs per ha and GHG.

3.2. Biomass Transportation. In this work, we assumed that switchgrass was collected from the field to the pyrolysis plant located in the center of the circle with radius $R_{\text {circle }}$. Overend [37] developed a model to compute the transportation distance between the point of harvesting biomass and the central processing plant:

$$
\text { (13) } R_{\text {circle }}=0.6833 \tau \sqrt{n / \phi} \sqrt{P / M} \text {. }
$$

$\tau$ is the tortuosity factor of the road; this is a function of the terrain and can range from 1.27 where a regular rectangular road grid is superimposed over a flat terrain to in excess of 3 for a complex or hilly terrain constrained by geographical features such as lakes and swamps. $n$ is the number of sectors to complete a circle. $\phi$ is the fraction of terrain devoted to switchgrass. $P$ is the pyrolysis plant scale in ton/day. $M$ is the switchgrass productivity in ton/(ha*year). It is assumed that switchgrass is transported by 20 tons semitrucks:

$$
A=\frac{P \times 330 \text { days }}{M \phi} \text { (ha). }
$$

$A$ is the area of switchgrass field in ha units. The switchgrass is assumed to be grown by farmers around the pyrolysis plant.

In Figure 2, switchgrass is grown in different farms in the upper right quadrant. The number of sectors to complete a circle is four since the circle was separated into four pieces. The fraction of terrain devoted to switchgrass is total area of every farm per area of the upper right quadrant. The red line is the road between a farm and a pyrolysis plant.

We assume that 20 tons of switchgrass is transported per truck. The truck mileage is assumed to be $2.4 \mathrm{~km} / \mathrm{L}$ [38]. The driver cost is assumed to be $\$ 0.6 /$ mile $(\$ 0.38 / \mathrm{km})$. We assume that $4 \%$ of switchgrass is lost during transportation.

In Figure 3, emission from transportation of switchgrass to storage depends on the distance from the field to storage and that means emission per ton of switchgrass increases as the plant capacity increases.

3.3. Land Use Change Effect. There are many studies reported on the carbon deposit into a soil after growing switchgrass. Planting switchgrass can increase the carbon deposit rate into $0.2-1.1 \mathrm{tC} /(\mathrm{ha} * \mathrm{a})$ [39]. The carbon dioxide was reported to be sequestered into the soil 1.79 tons of carbon dioxide per acre per year [40]. However, with the wide range of carbon deposit

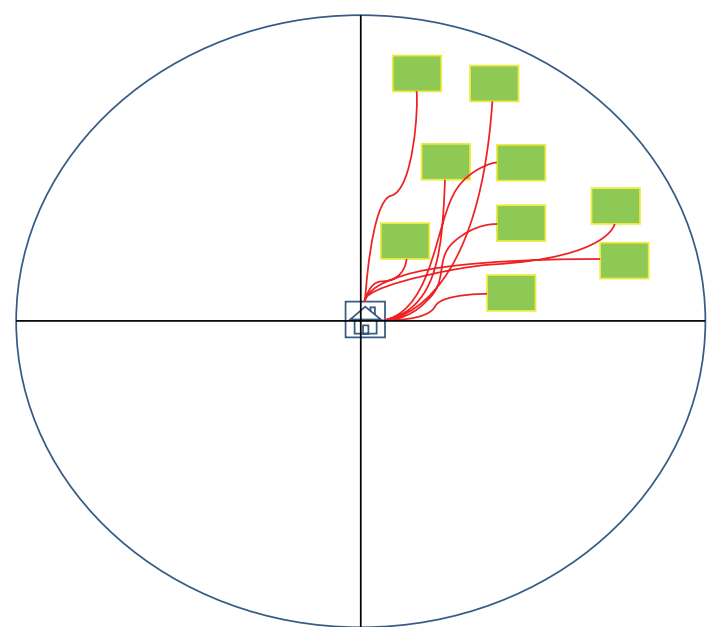

FIGURE 2: Calculating harvesting distance from farm to central pyrolysis plant.

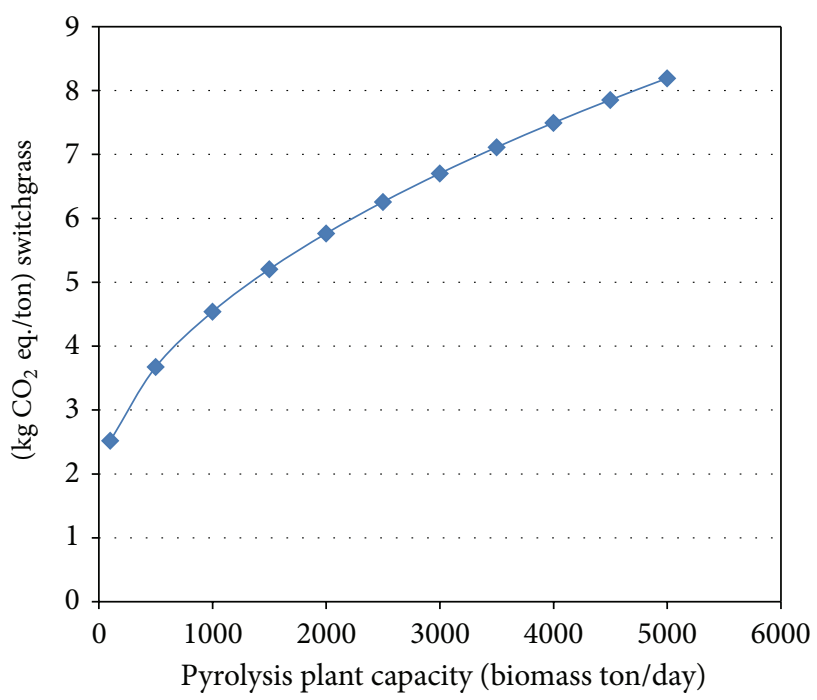

FIGURE 3: Dependence of emission from switchgrass transportation on pyrolysis plant capacity.

rate reported, the calculation is complex. The assumption is necessary. Cherubini and Jungmeier [41] gave an assumption of a $\mathrm{C}$ sequestration rate of $0.6 \mathrm{tC} /(\mathrm{ha} * \mathrm{a})$. In this work, the value of soil organic compound at 0.49 ton/acre/year is assumed for the first two years of establishment case and 1.5 ton/acre/year is assumed for mature crop case [42].

3.4. Storage. Table 5 shows initial construction costs of the selected storage systems (storage losses are not included). From Table 6, the pole frame structure-enclosed on crushed rock (used in our work) loses the least amount of switchgrass compared with other storage types. We assume that the labor cost is $\$ 12 /$ hour. The tractor cost is $\$ 20 /$ hour. The unload time and storage time for one truck are half hour. The unload time from storage is $20 \mathrm{~min}$. Emission from the storage process is $0.92 \mathrm{~kg} \mathrm{CO}_{2}$ eq. per ton of switchgrass. 
TABLE 2: The estimated costs of establishing switchgrass and GHG [30-34].

\begin{tabular}{|c|c|c|c|c|c|c|c|}
\hline \multicolumn{8}{|c|}{ The switchgrass } \\
\hline $\begin{array}{l}\text { Preharvest machinery operations custom } \\
\text { charges }\end{array}$ & $\$ /$ ha & Diesel (gal/ha) & $\begin{array}{c}\text { Diesel } \\
\text { cost } \$ / \text { ha }\end{array}$ & $\mathrm{CO}_{2}(\mathrm{~kg})$ & $\mathrm{N}_{2} \mathrm{O}$ & $\mathrm{CH}_{4}$ & $\begin{array}{l}\text { Estimate } \mathrm{CO}_{2} \\
\text { equivalent/ha }\end{array}$ \\
\hline Disk & 31.01 & $3.46(13.10 \mathrm{~L} / \mathrm{ha})$ & 12.97 & 37.10 & 0.0152 & 0.0020 & 41.85 \\
\hline Harrow & 19.10 & $1.24(4.69 \mathrm{~L} / \mathrm{ha})$ & 4.63 & 13.25 & 0.0054 & 0.0007 & 14.95 \\
\hline Airflow spreader (seed and fertilizers) & 31.26 & $1.48(5.60 \mathrm{~L} / \mathrm{ha})$ & 5.56 & 15.90 & 0.0065 & 0.0009 & 17.93 \\
\hline Spraying chemicals & 8.28 & $0.49(1.85 \mathrm{~L} / \mathrm{ha})$ & 1.85 & 5.30 & 0.0022 & 0.0003 & 5.98 \\
\hline Total & 89.65 & $6.67(25.25 \mathrm{~L} / \mathrm{ha})$ & 25.02 & 71.56 & 0.0292 & 0.0039 & 80.70 \\
\hline Operating expense & Price \$/unit & Unit/ha & $\$ /$ ha & & & & \\
\hline Seed & $\$ 7.5 / \mathrm{lb}(\$ 16.5 / \mathrm{kg})$ & $14.83 \mathrm{lb}(6.74 \mathrm{~kg})$ & 111.20 & & & & \\
\hline \multicolumn{8}{|l|}{ Fertilizer $^{*}$} \\
\hline $\mathrm{N}$ & $\$ 0.31 / \mathrm{lb}(\$ 0.68 / \mathrm{kg})$ & $264.55 \mathrm{lb}(120.25 \mathrm{~kg})$ & 82.01 & & 5.05 & 1.20 & 1590.94 \\
\hline $\mathrm{P}$ & $\$ 0.37 / \mathrm{lb}(\$ 0.81 / \mathrm{kg})$ & $74.13 \mathrm{lb}(33.70 \mathrm{~kg})$ & 27.43 & & & & \\
\hline $\mathrm{K}$ & $\$ 0.23 / \mathrm{lb}(\$ 0.51 / \mathrm{kg})$ & $98.84 \mathrm{lb}(44.93 \mathrm{~kg})$ & 22.73 & & & & \\
\hline Lime & $\$ 21 /$ ton & 7.41 ton & 155.68 & & & & \\
\hline Herbicides $^{* *}$ & & & & & & & 79.8 \\
\hline Pursuit + & $\$ 53 / \operatorname{gal}(\$ 14.00 / \mathrm{L})$ & $7.41 \mathrm{oz}(0.22 \mathrm{~L})$ & 3.06 & & & & \\
\hline MSO & $\$ 1.75 / p t(\$ 3.70 / \mathrm{L})$ & $79.07 \mathrm{oz}(2.34 \mathrm{~L})$ & 8.65 & & & & \\
\hline $2,4 \mathrm{D}$ & $\$ 16 /$ gal $(\$ 4.23 / \mathrm{L})$ & 3.71 pts $(1.76 \mathrm{~L})$ & 7.41 & & & & \\
\hline Total operating costs & 418.17 \$/ha & & & & & & \\
\hline $\begin{array}{l}\text { Total establishment (11 years at } 8 \% \\
\text { amortization (.14008 factor)) }\end{array}$ & $532.84 \$ / \mathrm{ha}$ & & & & & & \\
\hline Prorated yearly establishment cost per ha & $72.99 \$ / \mathrm{ha}$ & & & & & & \\
\hline
\end{tabular}

* The application of nitrogen fertilizer leads to the formation of nitrous oxide emissions from the soil which leads to emission of GHG.

** The emission of GHG from application of herbicide on a field.

TABLE 3: The estimated reseeding costs per hectare and GHG [30-34].

\begin{tabular}{|c|c|c|c|c|c|c|c|}
\hline \multicolumn{8}{|c|}{ Reseeding probability $25 \%$} \\
\hline $\begin{array}{l}\text { Preharvest machinery operations custom } \\
\text { charges }\end{array}$ & $\$ /$ ha & gal of diesel/ha & $\begin{array}{c}\text { diesel } \\
\text { cost/ha }\end{array}$ & $\mathrm{CO}_{2}$ & $\mathrm{~N}_{2} \mathrm{O}$ & $\mathrm{CH}_{4}$ & $\begin{array}{l}\text { Estimate } \mathrm{CO}_{2} \\
\text { equivalent/ha }\end{array}$ \\
\hline Airflow spreader (seed and fertilizer) & 31.26 & $1.48(0.70 \mathrm{~L} / \mathrm{ha})$ & 5.56 & 15.90 & 0.0065 & 0.00087 & 17.93 \\
\hline Spraying chemicals & 8.28 & $0.49(0.23 \mathrm{~L} / \mathrm{ha})$ & 1.85 & 5.30 & 0.0022 & 0.00029 & 5.98 \\
\hline Total & 39.54 & $1.97(0.93 \mathrm{~L} / \mathrm{ha})$ & 7.41 & 21.20 & 0.0087 & 0.00116 & 23.91 \\
\hline Operating exp. Price/unit Units & Price/unit & Unit/ha & $\$ /$ ha & & & & \\
\hline Seed & $\$ 7.5 / \mathrm{lb}(\$ 16.5 / \mathrm{kg})$ & $3.71 \mathrm{lb}(1.69 \mathrm{~kg})$ & 27.80 & & & & \\
\hline \multicolumn{8}{|l|}{ Fertilizer* } \\
\hline $\mathrm{N}$ & $\$ 0.31 / \mathrm{lb}(\$ 0.68 / \mathrm{kg})$ & $264.55 \mathrm{lb}(120 \mathrm{~kg})$ & 82.01 & & 5.05 & 1.20 & 1590.94 \\
\hline $\mathrm{P}$ & $\$ 0.37 / \mathrm{lb}(\$ 0.81 / \mathrm{kg})$ & $74.13 \mathrm{lb}(32.62 \mathrm{~kg})$ & 27.43 & & & & \\
\hline K & $\$ 0.23 / \mathrm{lb}(\$ 0.51 / \mathrm{kg})$ & $98.84 \mathrm{lb}(44.83 \mathrm{~kg})$ & 22.73 & & & & \\
\hline Herbicides $^{* *}$ & & & & & & & 79.8 \\
\hline Pursuit + & $\$ 53 / \operatorname{gal}(\$ 14.00 / \mathrm{L})$ & $7.41 \mathrm{oz}(0.22 \mathrm{~L})$ & 3.06 & & & & \\
\hline MSO & $\$ 1.75 / p t(\$ 3.70 / \mathrm{L})$ & $79.07 \mathrm{oz}(2.34 \mathrm{~L})$ & 8.65 & & & & \\
\hline $2,4 \mathrm{D}$ & $\$ 16 /$ gal $(\$ 4.23 / \mathrm{L})$ & 3.71 pts $(1.76 \mathrm{~L})$ & 7.41 & & & & \\
\hline Total operating costs & $179.09 \$ / \mathrm{ha}$ & & & & & & \\
\hline $\begin{array}{l}\text { Total reseeding costs (10 years at } 8 \% \\
\text { amortization ( } .14903 \text { factor }))\end{array}$ & $226.04 \$ /$ ha & & & & & & \\
\hline Prorated yearly reseed cost per ha & $32.91 \$ / \mathrm{ha}$ & & & & & & \\
\hline
\end{tabular}

${ }^{*}$ The application of nitrogen fertilizer leads to the formation of nitrous oxide emissions from the soil which leads to emission of GHG.

${ }^{* *}$ The emission of GHG from application of herbicide on a field. 
TABLE 4: The estimated yearly production costs per hectare and GHG [30-34].

\begin{tabular}{|c|c|c|c|c|c|c|c|}
\hline \multicolumn{8}{|c|}{ Estimated yearly production costs } \\
\hline Expected yield per ha & 9 tons & & & & & & \\
\hline Weight of large square bale & $950 \mathrm{lbs}$ & $431.82 \mathrm{~kg}$ & & & & & \\
\hline Bales per ha & 20.84 & & & & & & \\
\hline $\begin{array}{l}\text { Pre-harvest machinery operations } \\
\text { custom charges }\end{array}$ & $\$ /$ ha & gal of diesel/ha & $\begin{array}{c}\text { diesel } \\
\text { cost/ha }\end{array}$ & $\mathrm{CO}_{2}$ & $\mathrm{~N}_{2} \mathrm{O}$ & $\mathrm{CH}_{4}$ & $\begin{array}{l}\text { Estimate } \mathrm{CO}_{2} \\
\text { equivalent/ha }\end{array}$ \\
\hline Bulk fertilizer spreader & 8.28 & $0.49(1.85 \mathrm{~L} / \mathrm{ha})$ & 1.85 & 5.30 & 0.0022 & 0.00029 & 5.978 \\
\hline Liquid $\mathrm{N}$ application and sprayer & 17.42 & $1.48(5.60 \mathrm{~L} / \mathrm{ha})$ & 5.56 & 15.90 & 0.0065 & 0.00087 & 17.93 \\
\hline Total & 25.70 & $1.97(7.46 \mathrm{~L} / \mathrm{ha})$ & 7.41 & 21.20 & 0.0087 & 0.00116 & 23.91 \\
\hline Operating Exp. Price/unit Units & Price \$/unit & Unit/ha & $\$ /$ ha & & & & \\
\hline \multicolumn{8}{|l|}{ Fertilizer $^{*}$} \\
\hline $\mathrm{N}$ & $\$ 0.31 / \mathrm{lb}(\$ 0.68 / \mathrm{kg})$ & $247.11 \mathrm{lb}(112.09 \mathrm{~kg})$ & 76.60 & & 4.72 & 1.12 & 1486.00 \\
\hline $\mathrm{P}$ & $\$ 0.37 / \mathrm{lb}(\$ 0.81 / \mathrm{kg})$ & $4.79 \mathrm{lb}(2.17 \mathrm{~kg})$ & 1.77 & & & & \\
\hline $\mathrm{K}$ & $\$ 0.23 / \mathrm{lb}(\$ 0.51 / \mathrm{kg})$ & $56.34 \mathrm{lb}(25.56 \mathrm{~kg})$ & 12.96 & & & & \\
\hline Herbicides $^{* *}$ & & & & & & & 79.8 \\
\hline Pursuit + & $\$ 53 /$ gal $(\$ 14.00 / \mathrm{L})$ & $7.41 \mathrm{oz}(0.22 \mathrm{~L})$ & 3.06 & & & & \\
\hline MSO & $\$ 1.75 / p t(\$ 3.70 / \mathrm{L})$ & $79.07 \mathrm{oz}(2.34 \mathrm{~L})$ & 8.65 & & & & \\
\hline $2,4 \mathrm{D}$ & $\$ 16 / \operatorname{gal}(\$ 4.23 / \mathrm{L})$ & 3.71 pts $(1.76 \mathrm{~L})$ & 7.41 & & & & \\
\hline \multicolumn{8}{|l|}{ Total operation cost } \\
\hline $\begin{array}{l}\text { Harvest machinery operations, custom } \\
\text { charges }\end{array}$ & Cost without fuel (\$/ha) & gal of diesel/ha & $\begin{array}{c}\text { diesel } \\
\text { cost/ha }\end{array}$ & & & & \\
\hline Mow/conditioning & 36.37 & 2.792 (10.57 L/ha) & 10.47 & 29.95 & 0.012 & 0.0016 & 33.76 \\
\hline Rake & 13.81 & $0.766(2.90 \mathrm{~L} / \mathrm{ha})$ & 2.87 & 8.216 & 0.003 & 0.0004 & 9.27 \\
\hline Baling: large square & 45.22 & $2.644(10.01 \mathrm{~L} / \mathrm{ha})$ & 9.92 & 28.36 & 0.012 & 0.0015 & 31.98 \\
\hline Staging & 49.42 & $2.471(9.35 \mathrm{~L} / \mathrm{ha})$ & 9.27 & 26.50 & 0.011 & 0.0014 & 29.89 \\
\hline Total & 144.83 & $8.67(32.82 \mathrm{~L} / \mathrm{ha})$ & 32.53 & 114.2 & 4.764 & 1.1294 & 1694.63 \\
\hline Yearly production costs per ha & $320.92 \$ /$ ha & & & & & & \\
\hline Prorated establishment cost & 72.99 & & & & & & \\
\hline Prorated reseeding cost & 32.91 & & & & & & \\
\hline Total production costs & 426.82 & & & & & & \\
\hline Production costs per ton & 47.42 & & & & & & \\
\hline
\end{tabular}

* The application of nitrogen fertilizer leads to the formation of nitrous oxide emissions from the soil which leads to emission of GHG.

** The emission of GHG from application of herbicide on a field.

TABLE 5: Initial construction costs of the selected storage systems (storage losses are not included) [35].

\begin{tabular}{|c|c|c|c|c|c|}
\hline $\begin{array}{l}\text { Storage system for square bales } \\
(950 \mathrm{lb} / \mathrm{bale})\end{array}$ & Cost per $\mathrm{m}^{2}(\$)$ & Life years & $\begin{array}{l}\text { Annual costs } \\
\left(\$ / \mathrm{m}^{2}\right)\end{array}$ & Cost per bale $(\$)$ & Cost per ton $(\$)$ \\
\hline \multirow{2}{*}{ Collective storage facility } & \multirow{2}{*}{107.64} & \multirow{2}{*}{15} & \multirow{2}{*}{12.58} & \multirow{2}{*}{$\begin{array}{c}10 \text { bales high } \\
3.77\end{array}$} & \multirow[b]{2}{*}{7.95} \\
\hline & & & & & \\
\hline $\begin{array}{l}\text { Pole frame structure-enclosed on } \\
\text { crushed rock }\end{array}$ & $70.39-107.64$ & 15 & $8.22-12.58$ & $\begin{array}{cc}5 \text { bales high } & 6 \text { bales high } \\
4.93-7.55 & 4.11-6.29\end{array}$ & $\begin{array}{cc}5 \text { bales high } & 6 \text { bales high } \\
10.39-15.89 & 8.66-13.24\end{array}$ \\
\hline \multirow{2}{*}{$\begin{array}{l}\text { Reusable tarp on crushed rock } \\
\text { (19.8 sq. ft/bale i.e., } 1.84 \mathrm{~m}^{2} / \text { bale) }\end{array}$} & \multirow{2}{*}{1.47} & \multirow{2}{*}{5} & \multirow{2}{*}{0.37} & 4 bales high & 4 bales high \\
\hline & & & & 1.39 & 2.92 \\
\hline $\begin{array}{l}\text { Outside Unprotected on crushed } \\
\text { rock }\end{array}$ & 2.70 & 5 & 0.68 & 0.51 & 1.07 \\
\hline Outside and unprotected on ground & 0.00 & - & 0.00 & 0.00 & 0.00 \\
\hline
\end{tabular}


TABLE 6: Storage systems and expected dry matter loss [35].

\begin{tabular}{lc}
\hline Storage system for square bales (950 lb/bale) & $\begin{array}{c}\text { Average } \\
\text { DM loss (\%) }\end{array}$ \\
\hline Pole frame structure-enclosed on crushed rock & 2 \\
Pole frame structure-open sides on crushed rock & 4 \\
Reusable tarp on crushed rock & 7 \\
Outside Unprotected on crushed rock & 15 \\
Outside and unprotected on ground & 25 \\
\hline
\end{tabular}

TABLE 7: Biorefinery capital cost components based on the reference plant size [36].

\begin{tabular}{lc}
\hline \multicolumn{1}{c}{$\begin{array}{c}\text { Capital cost } \\
\text { Fast pyrolysis (28 mmgpy bio-oil) }\end{array}$} & Cost (millions) \\
\hline Handling and drying & 5.57 \\
Pyrolysis reactor & 3.92 \\
Quench & 1.94 \\
Heat recovery & 1.14 \\
Product recovery and storage & 0.8 \\
Recycle & 1.38 \\
Steam and power production & 3.16 \\
Utilities & 3.13 \\
Contingency & 7.37 \\
\hline Total & 28.41 \\
\hline
\end{tabular}

3.5. Pyrolysis Oil Production. In this paper we have chosen pyrolysis for producing biooil. Boateng et al. [15] designed a bench-scale pyrolysis reactor to convert switchgrass to biooil. We assumed a pyrolysis plant based on the authors' work. Results from the authors show that switchgrass pyrolysis could yield over $85 \%$ of mass basis. The product consists of biooil $60.7 \%$, biochar $11.3 \%$, and noncondensable gas $12.9 \%$ in mass basis. The noncondensable gas consists of $\mathrm{CO}_{2} 29 \%$, $\mathrm{CO} 57.6 \%, \mathrm{H}_{2} 5.1 \%$, and $\mathrm{CH}_{4} 7.8 \%$ by volume. In this work, the biooil product is assumed to be $60.7 \%$ wt as the lowest yield for switchgrass that author suggested. The pyrolysis oil is assumed to be transported by a tank truck capacity of 11600 US gallons. The mileage of the tank truck is $2.4 \mathrm{~km} / \mathrm{L}$ [38]. Emission from the storage process is $6.2 * 10^{-3} \mathrm{~kg} \mathrm{CO}_{2}$ eq. per ton of switchgrass.

Table 7 shows the biorefinery capital cost while Table 8 shows the operating cost for the plant. Table 9 shows production from pyrolysis of switchgrass. Properties of pyrolysis oil are shown in Table 10.

3.6. Power Generation. Power generation from fossil fuels is one of the major greenhouse gas producers, an estimated onethird of the carbon dioxide emissions in Europe. The pyrolysis oil can be used as a substitute of fossil fuels in conventional power plants such as gas engines, gas turbines, and coal fired plants in order to reduce greenhouse gas emissions. Pyrolysis oil is acidic, unstable, contains solid residue, and many chemicals in biooil dissolve in water. The heating value, density, and viscosity of biooil depend on water and additives in the biooil, which also differs from fossil fuels. These factors
TABLE 8: Biomass fast pyrolysis annual operating cost components based on the reference plant size [36].

\begin{tabular}{lcc}
\hline Fast pyrolysis operation cost & Cost & Explanation \\
\hline Water treatment & 1 & Linear scaling \\
Electricity & 0.21 & Linear scaling \\
Labor & 1.34 & 0.6 power law scaling \\
Overhead & 0.8 & $60 \%$ labor \\
Maintenance & 0.57 & $2 \%$ equip \\
Insurance/taxes & 0.72 & $1.5 \%$ TCI \\
Charcoal (credit) & 1.92 & $50 /$ ton \\
\hline
\end{tabular}

TABLE 9: Production from pyrolysis of switchgrass [15].

\begin{tabular}{lc}
\hline Product & $\% \mathrm{wt}$ \\
\hline Biooil & $60.7 \%$ \\
Biochar & $11.3 \%$ \\
Noncondensable gas & $12.9 \%$ \\
\hline
\end{tabular}

TABle 10: Properties of pyrolysis oil [15].

\begin{tabular}{lc}
\hline Property & \\
\hline Density at $15^{\circ} \mathrm{C}, \mathrm{kg} / \mathrm{L}$ & 1.25 \\
Kinematic viscosity at $50^{\circ} \mathrm{C}, \mathrm{cSt}$ & 13.11 \\
Kinematic viscosity at $100^{\circ} \mathrm{C}, \mathrm{cSt}$ & 2.54 \\
Heat of combustion, $\mathrm{MJ} / \mathrm{kg}$ & 16.02 \\
Ash at $775^{\circ} \mathrm{C}, \mathrm{wt} \%$ & 0.01 \\
\hline
\end{tabular}

TABle 11: Power plant efficiency.

\begin{tabular}{lcc}
\hline Power plant & Efficiency & Reference \\
\hline Diesel engine & $32.4 \%$ & {$[13]$} \\
Gas turbines & $42 \%$ & {$[43]$} \\
Steam turbine coal-fired power plant & $33 \%$ & {$[43]$} \\
Steam turbine fuel-oil power plant & $34 \%$ & {$[44]$} \\
\hline
\end{tabular}

are problematic in using pyrolysis oil in conventional power plants. Despite these problems, biooil still can be used in the conventional power plants by modifying the engines as many studies suggest [7, 13]. Balat et al. [48] also suggested the main route of using the biooil in boilers, diesel engines, or gas turbines for heat and electricity generation. In this work, the power plant is assumed to operate 8760 hour/year. The main power technologies considered in this work are discussed below.

Table 11 shows power plants efficiency. Table 12 shows specification on wt\% of pyrolysis liquid component (to be able to use as fuel in boilers, engines and turbines). Comparing specification pyrolysis oil from Oasmaa et al. with pyrolysis oil from switchgrass, we assume that the pyrolysis oil from switchgrass can be used in boilers, engines, and turbines.

3.6.1. Diesel Engine Power Plant. Yoshikawa [49] studied the efficiency of the diesel engine in power plants when using low-BTU fuel gas which was produced by pyrolized solid fuel. 
TABLE 12: Specification on wt $\%$ of pyrolysis liquid component (to be able to use as fuel in boilers, engines, and turbines) [45].

\begin{tabular}{lcc}
\hline Component & $\begin{array}{c}\text { Specification } \\
\text { to be met }\end{array}$ & $\begin{array}{c}\text { Pyrolysis oil from } \\
\text { reference switchgrass } \\
{[15]}\end{array}$ \\
\hline Water & $<27 \mathrm{wt} \%$ & $23 \mathrm{wt} \%$ \\
Total solids & $<0.01 \mathrm{wt} \%$ & $0.01 \mathrm{wt} \%^{*}$ \\
Inorganics & $<0.01 \mathrm{wt} \%$ & $0.01 \mathrm{wt} \%^{*}$ \\
\hline
\end{tabular}

${ }^{*}$ Ash content.

The result showed that the efficiency of diesel engines was about 30\%. Solantausta et al. [50] reported the efficiency of $34 \%$ using pyrolysis oil in diesel. In this paper, the thermal efficiency of diesel engines which use pyrolysis oil is assumed to be $32.4 \%$ [13].

\subsubsection{Pyrolysis Oil Substituting Natural Gas in Gas Turbines.} In order to use pyrolysis oil in gas turbines, the gas turbine engine must be modified and pyrolysis oil needs to be upgraded. The gas turbine engine must be able to resist low $\mathrm{pH}$ substance which is pyrolysis oil. The nozzles must be modified for higher flow cause by lower heating value and higher viscosity of pyrolysis oil. The preheating unit to heat the pyrolysis oil to $70-90^{\circ} \mathrm{C}$ is necessary to reduce the viscosity of pyrolysis oil to less than $10 \mathrm{cSt}$ [13]. However, Wagenaar et al. [51] reported the use of biooil to substitute the natural gas in the real power plant. The experiment showed the possibility of using pyrolysis oil in the gas turbine power plant. Herdin et al. [52] reported that the efficiency of gas turbine for electric generation using natural gas was $45 \%$. In this paper, the efficiency of pyrolysis oil in gas turbines engine is assumed to be $42 \%$ which is the same as Jaramillo's dissertation.

3.6.3. Steam Turbine Generator. In this work, pyrolysis oil is being used as a replacement for coal and fuel oil in a steam turbine generator. Steam turbine generators use fuel combustion in a boiler to produce steam. Next, steam is injected into steam turbine to generate electricity. Normally, steam turbines have a lower efficiency compared to a reciprocating engine such as diesel engine or gas turbines but overall efficiency can be higher [53]. In order to operate the boiler with pyrolysis oil, some modification is needed to improve combustion stability. A support fuel is needed to start up the boiler. In case of low quality pyrolysis oil, support fuel is needed during operation. Pyrolysis oil has a longer flame than standard fuel oil. Schreiner et al. [54] investigated the use of biomass pyrolysis in the coal power plant. Their work showed promising result. The combustion of pyrolysis oil in the boiler is clean and efficient [55]. In this work, we assume that operating a coal power plant by using pyrolysis oil is going to give the same $33 \%$ efficiency as using coal in the operation [43]. Using pyrolysis oil as a substitution of fuel oil is assumed to have an efficiency of $34 \%$ [44].

Annual capital, operation and maintenance cost per kilowatt year for different power plants are shown in Table 13.
TABLE 13: Power generation capital, operation and maintenance cost per kWyr for different power plants [46].

\begin{tabular}{lcc}
\hline System & $\begin{array}{c}\text { Annual fixed } \\
\text { capital cost, \$/kWyr }\end{array}$ & $\begin{array}{c}\text { Annual fixed operation } \\
\text { and maintenance cost, } \\
\$ / \mathrm{kWyr}\end{array}$ \\
\hline $\begin{array}{l}\text { Diesel engine } \\
\begin{array}{l}\text { Natural-gas-fired } \\
\text { combustion turbine }\end{array}\end{array}$ & 75.00 & 3.00 \\
Coal-fired steam cycle & 120.00 & 3.25 \\
Oil-fired steam cycle & 96.00 & 6.25 \\
\hline
\end{tabular}

\section{Result and Discussion}

This work views the switchgrass as a source of energy for different power plants. The LCA and LCC are used for understanding total emission and economics over the pyrolysis of switchgrass from cradle to grave. We started by calculating all impacts from growing switchgrass in an empty field to a final user, which is a power plant. The mass and energy balance is applied in this work to calculate the life cycle assessment.

4.1. Pyrolysis Plant Capacity Effect. In this study, the different capacities of pyrolysis plant from 100 ton per day to 5000 ton per day of switchgrass are assumed to be used to produce pyrolysis oil. The effect of the pyrolysis plant capacity will be shown in both the LCA and LCC. The total GHG emission, area used to grow switchgrass, switchgrass price, pyrolysis oil price, and electric price are affected by the capacity of pyrolysis plants. We assume that the distance from the pyrolysis plant to the power plant was $60 \mathrm{~km}$.

4.2. Switchgrass Production. The switchgrass price per ton is considered by two life cycle stages: (1) switchgrass cultivation and harvesting and (2) transportation. In this analysis, the switchgrass is grown in a circular field, which has a land fraction of 0.441 of a field. This land faction is the same as the average agriculture land fraction for the USA [56].

Figure 4 shows that the price of switchgrass is increased by increasing the capacity of the pyrolysis plant. For example, if the pyrolysis plant capacity increases from 100 tons per day to 5000 tons per day, the switchgrass price increases more than one dollar per ton from $\$ 120.53$ to $\$ 121.72$ per ton. The price increase is due to the longer delivery distance for the switchgrass and the bigger area needed for switchgrass harvesting.

4.3. Area of Switchgrass Field. Normally, the area to grow switchgrass gets larger as the capacity of the pyrolysis plant increases. In this study, the loss of the switchgrass in transportation and processing is approximately $4 \%$ weight [57]. We chose a pole frame structure-enclosed on crushed rock as a storage system because it loses only $2 \%$ [35] weight of the switchgrass in storage. Even if the price of building storage in the pole frame is high, we lose less switchgrass from this storage. As a result, we need less area to grow it. The land 


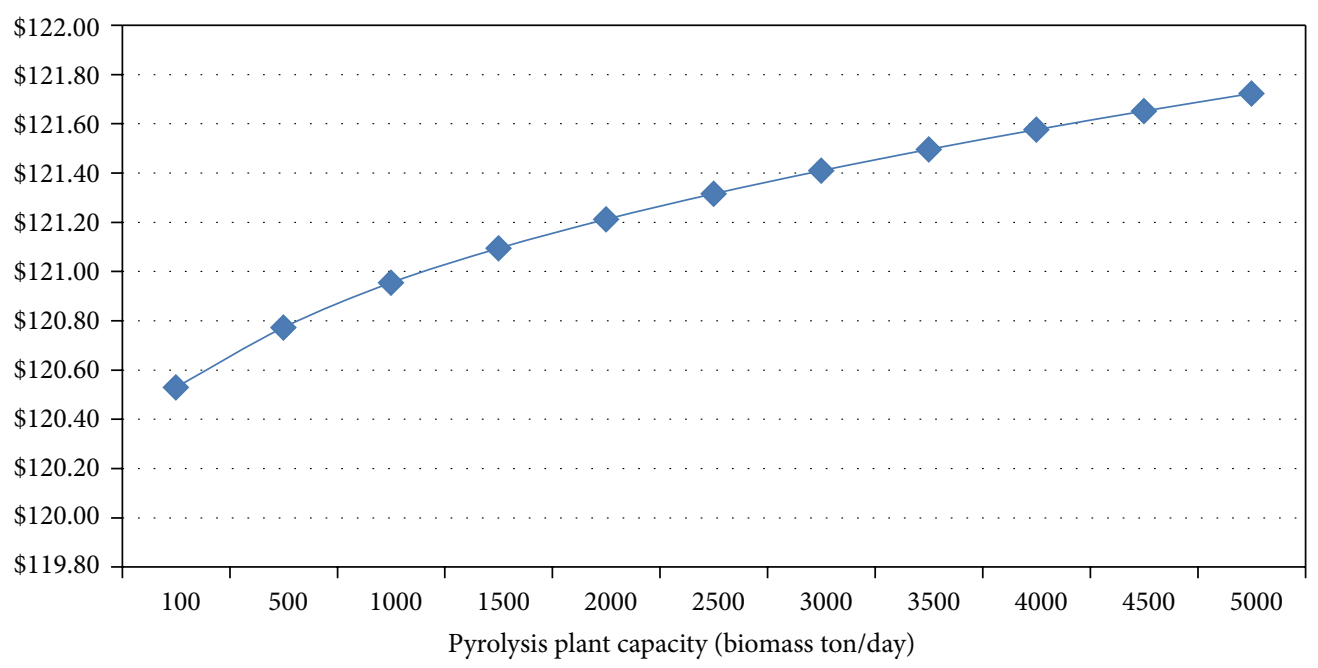

FIGURE 4: Switchgrass price versus pyrolysis plant capacity.

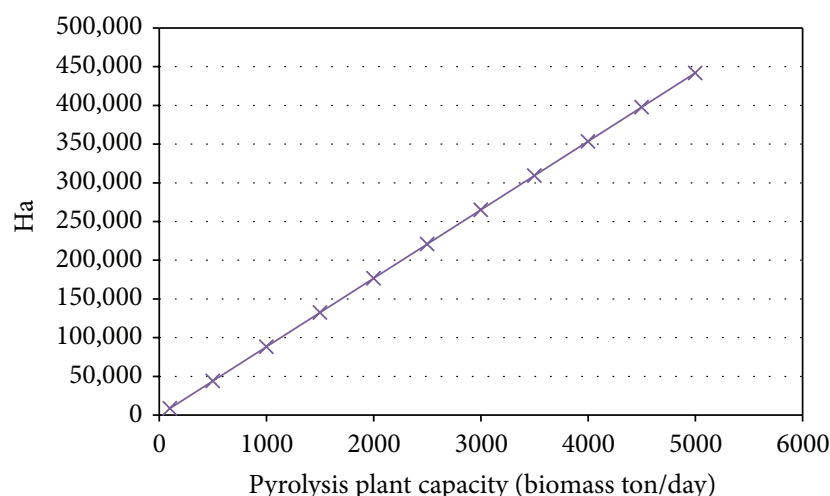

FIGURE 5: Area of switchgrass field varies by pyrolysis plant capacity.

fraction used for switchgrass was 0.441 in a circular shape field.

From Figure 5, the area is a linear function of the capacity. The area of switchgrass field is $8837.6 \mathrm{Ha}$ for fulfill pyrolysis plant at capacity of 100 tons per day and the area is $441880 \mathrm{Ha}$ in capacity of 5000 tons per day of pyrolysis plant. The $441880 \mathrm{Ha}$ is a huge area that is even bigger than the land area of Rhode Island. The Rhode Island land area is 1034 square miles or $267805 \mathrm{Ha}$.

4.4. Pyrolysis Oil Production. In this study, in order to produce pyrolysis oil from switchgrass, there are three life cycle stages: (1) switchgrass cultivation and harvesting; (2) transportation; (3) storage. Pyrolysis plant produced three products: NCG, pyrolysis oil, and biochar. The ratio of pyrolysis oil produced is $60.7 \% \mathrm{w} / \mathrm{w}$. NCG is $12.9 \% \mathrm{w} / \mathrm{w}$ and biochar is $11.3 \% \mathrm{w} / \mathrm{w}$. The NCG and biochar are used in the pyrolysis plant as an energy source to operate the pyrolysis plant. Therefore, the net product from this plant is only pyrolysis oil, which is assumed to be sold to different power plants as a substituted energy source.

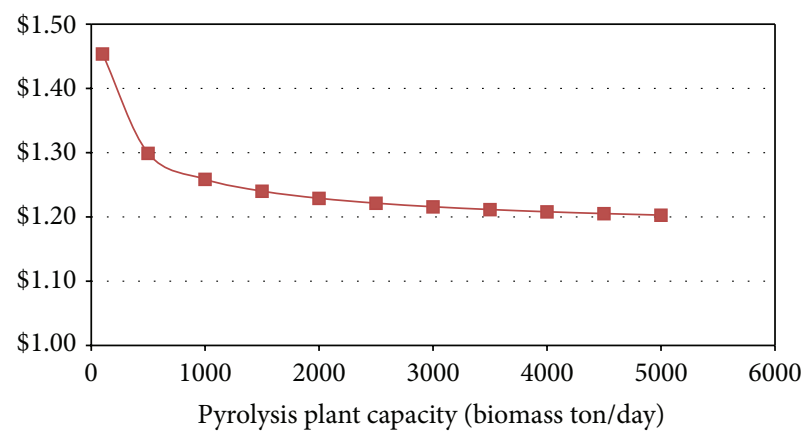

FIGURE 6: Pyrolysis oil price versus pyrolysis plant capacity.

From Figure 6, the pyrolysis oil price decreases, while the pyrolysis plant size increases. The price of pyrolysis oil is $\$ 1.45$ per gal at a capacity of 100 tons per day, while pyrolysis oil price reduces to $\$ 1.20$ per gal at a capacity of 5000 tons per day.

4.5. Electricity Produced by Pyrolysis Oil in Different Power Plants. In order to produce electricity from switchgrass, we considered four life cycle stages: (1) switchgrass cultivation and harvesting; (2) transportation and storage; (3) pyrolysis production and transportation; (4) electric generator. There are four kinds of power plants: (a) diesel engine power plant; (b) natural-gas-fired combustion turbine power plant; (c) coal-fired steam-cycle power plant; and (d) oil-fired steamcycle power plant. The Natural-gas-fired combustion turbine power plant is the most efficient plant having an efficiency of $42 \%$, while the diesel engine power plant is the lowest efficiency at $32.4 \%$. The coal-fired steam-cycle power plant and oil-fired steam cycle power plant have an efficiency of $33 \%$ and $34 \%$, respectively.

From Figure 7, it can be concluded that the natural-gasfired combustion turbine will produce a higher amount of electricity $(11.44 \mathrm{Mw})$ than the diesel engine $(8.83 \mathrm{Mw})$, when 


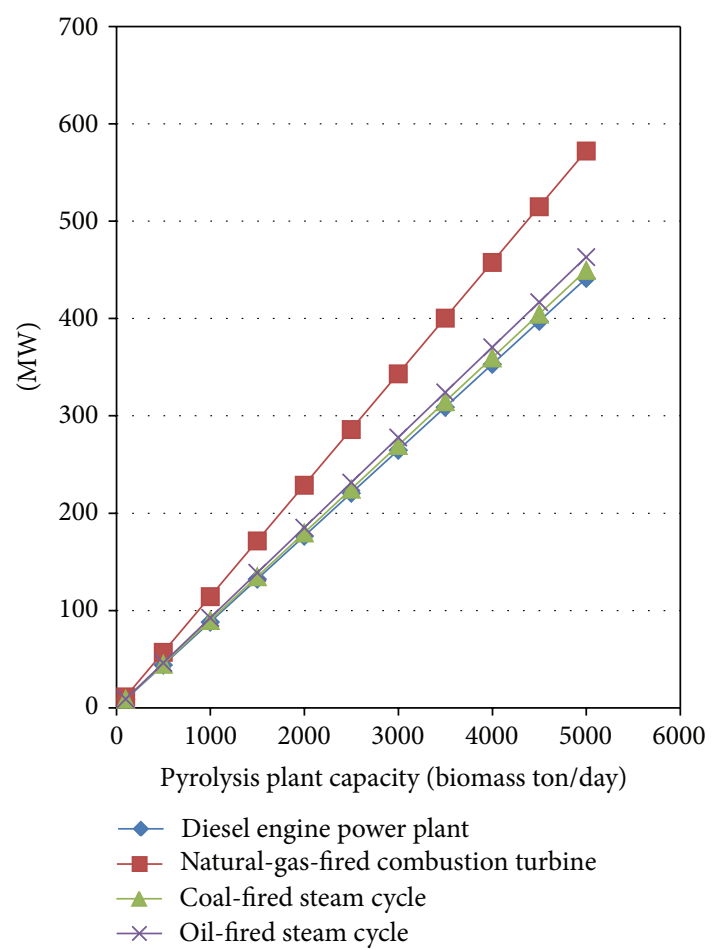

FIGURE 7: Electricity produced by different power plants varies with pyrolysis plant capacity.

both are supplied with equal amounts of pyrolysis oil from a plant of capacity 100 tons per day. At a plant capacity of 5000 tons per day, the natural-gas-fired combustion turbine produces $572.13 \mathrm{Mw}$, while the diesel engine could produce 441.36 Mw. With $572.13 \mathrm{Mw}$ of electricity or 5011.86 million kilowatt-hours, it can provide enough electricity for all the state of Hawaii requirement. From the report of the U.S. Energy Information Administration in 2012 [58], Hawaii consumed 4723 million kilowatt-hours.

From Figure 8, it can be concluded that because the natural-gas-fired combustion turbine is the most efficient power plant compared with others, it produces the cheapest electricity. The pyrolysis plant capacity of 100 tons of switchgrass can supply the natural-gas-fired combustion turbine to produce electricity at a price of $\$ 0.15$ per kwh. The price could drop to $\$ 0.12$ per kwh with the pyrolysis plant at a capacity of 5000 tons per day. The highest electric price was produced by the coal-fired steam cycle since the capital cost and maintenance cost are the highest. The electric cost was $\$ 0.20$ per kwh for the pyrolysis plant at capacity of 100 tons per day. The price could drop to $\$ 0.17$ per kwh for the pyrolysis plant at capacity of 5000 tons per day. From the U.S. Energy Information Administration [59], the average electricity cost in the United States in 2011 was $\$ 0.10$ per kwh. From the analysis, the cost of electricity from combustion of biooil is higher than the normal average electricity cost in the United States.

4.6. GHG Emission per kwh. The GHG emission per kwh is shown in Figure 9. Because the average agricultural land in

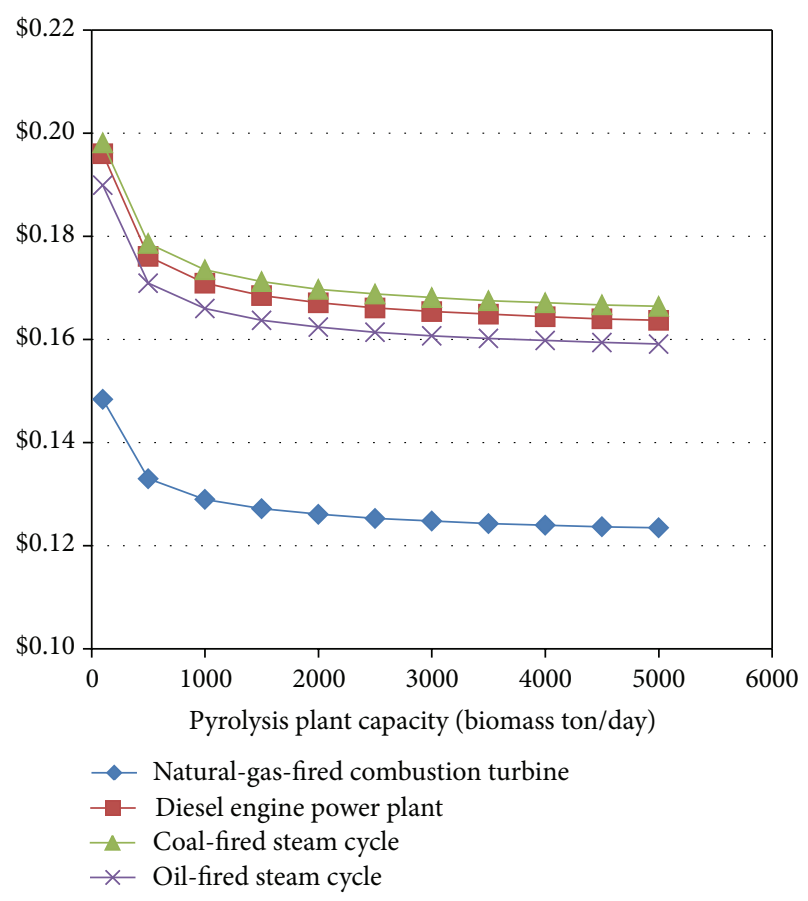

Figure 8: Price of electricity in different power plants versus pyrolysis plant capacity.

the US is about $44.1 \%$ [56] of the entire US land, we assume that the average percentage of land use to grow switchgrass is $44.1 \%$ (land fraction). The land shape was assumed to be circular. The total GHG emission per kwh of using pyrolysis oil from switchgrass is negative because carbon dioxide is sequestrated into the soil while growing switchgrass. The value of soil organic compound increasing at the rate of 0.49 ton/acre/year is used for the first two years of establishment and reseeding case [42] and 1.5 ton/acre/year is used for mature crop case. The natural-gas-fired combustion turbine seems to have higher GHG emission per kwh because this power plant was assumed to have the highest efficiency at $42 \%$ while others have efficiency around $32-34 \%$. In order to calculate GHG emission per kwh, firstly we calculate an accumulation of GHG emission from starting of seeding year through the end of switchgrass live cycle at the eleventh year. Secondly, we average the total GHG emission per kwh, which is produced during nine years of operation of the power plant.

As demonstrated in Figure 9, because the natural-gasfired combustion turbine is the most efficient power plant, which generated most electricity, its GHG emission per kwh is the highest. However, all the GHG results are negative which mean the GHG is adsorbed to the system. Results from Figure 9 show that the pyrolysis plant capacity almost has no effect, or only a small increasing effect, on GHG emission while the capacity gets higher. From the results of LCA, pyrolysis of switchgrass was totally clean energy which can reduce the GHG emission.

4.7. Distance from Pyrolysis Plant to Power Plant Effect. From Figure 10, the price of pyrolysis oil is higher if the 


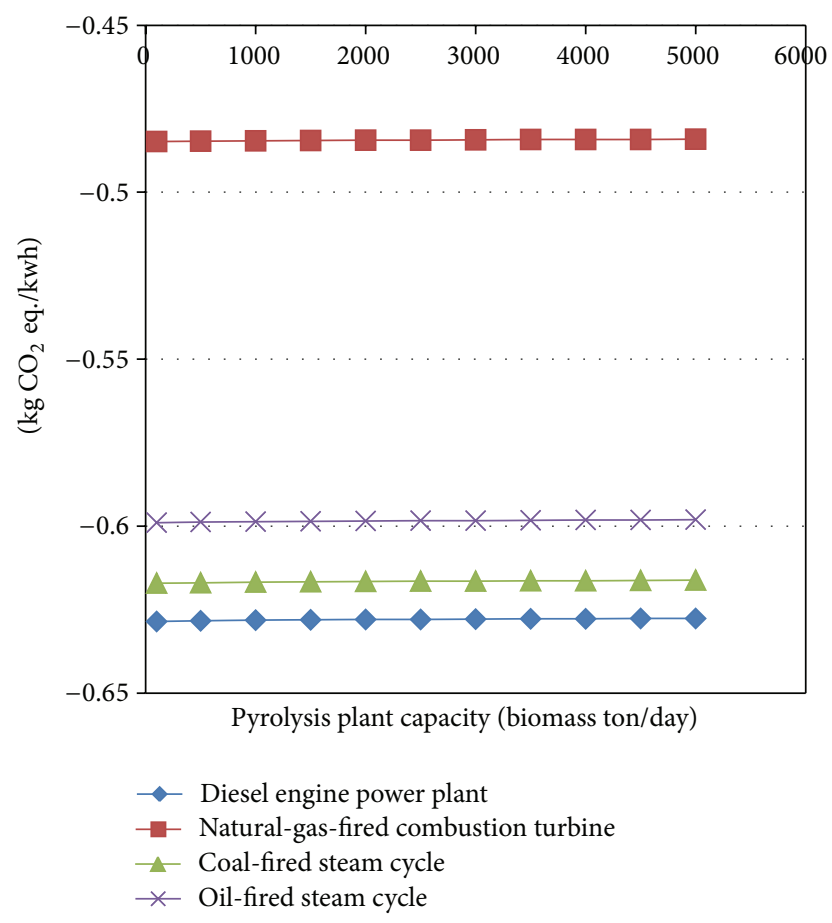

FIGURE 9: Variation of total emission (of different power plants) with pyrolysis plant capacity.

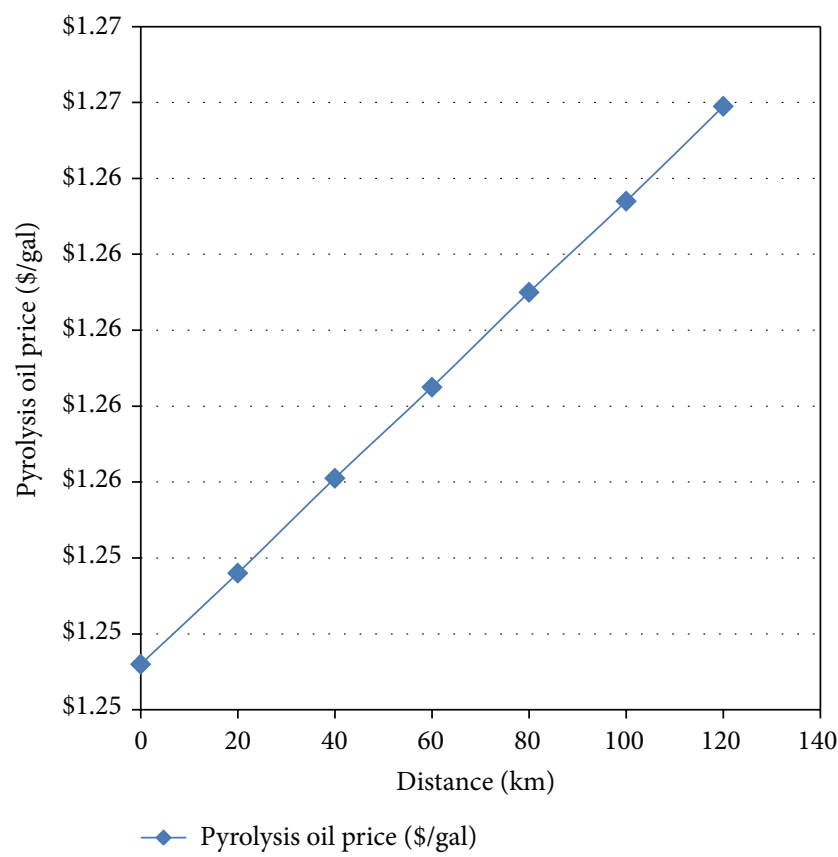

FIGURE 10: Dependence of price of pyrolysis oil on distance from pyrolysis plant to power plant (\$/gal).

distance between the pyrolysis plant and the power plant is larger. However, the pyrolysis oil price varies slightly with the distance. At zero distance, which meant the pyrolysis plant and the power plant are at the same location, pyrolysis oil price is $\$ 1.251$ per gal. When the distance between the

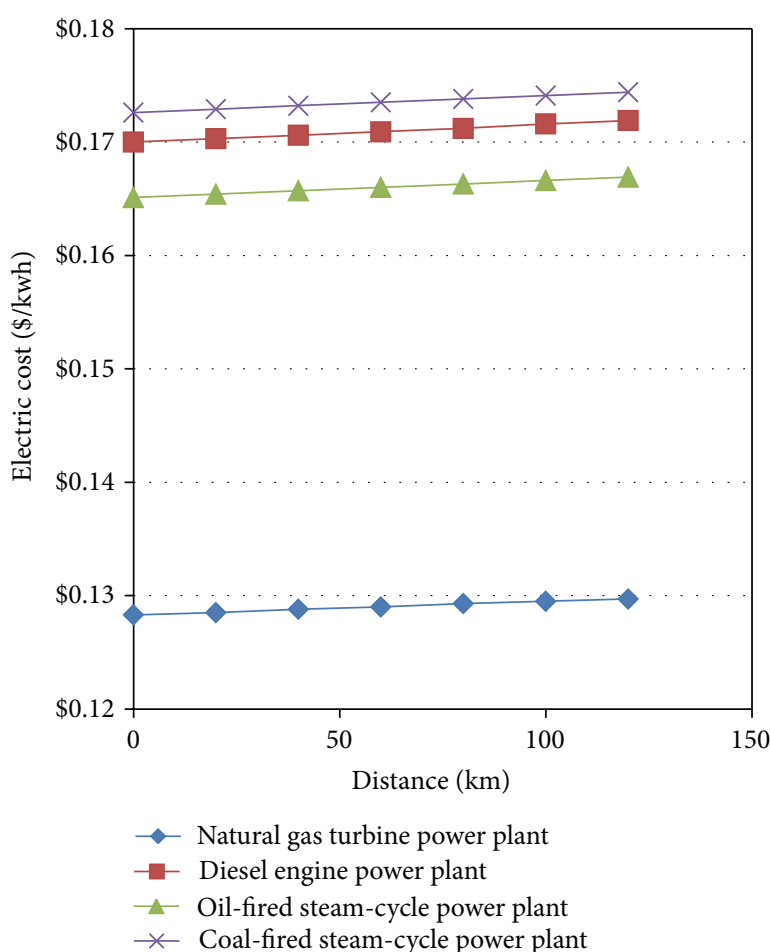

FIGURE 11: Dependence of electric cost on distance between pyrolysis plant and power plant $(\$ / \mathrm{kwh})$.

pyrolysis plant and the power plant is $120 \mathrm{~km}$, the pyrolysis oil price is $\$ 1.266$ per gal.

In Figure 11, the distance from the pyrolysis plant and the power plant had a minor effect on the electricity cost. The type of power plant is the determining factor for decreasing electricity cost. The natural gas turbine power plant produces the cheapest electricity. At zero distance, the electricity cost was 12.83 cent per kwh. At $120 \mathrm{~km}$, the electricity cost is 12.97 cent per kwh. The most expensive electricity cost comes from substituting pyrolysis oil into the coal-fired steam-cycle power plant. At zero distance, the electricity cost is $17.26 \mathrm{cent}$ per kwh. At $120 \mathrm{~km}$, the electricity cost increases to 17.44 cent per kwh. At these electricity costs, substituting pyrolysis oil in the power plant is not competitively priced compared to fossil fuel.

From Figure 12, the distance between the pyrolysis plant and the power plant has a minor effect on GHG emission per kwh. The type of power plant has affected GHG emission per kwh more so than the distance. All of the power plants, which used pyrolysis oil substituted for fossil fuel, had negative GHG emission. The most negative GHG emission per kwh comes from the diesel engine power plant. At zero distance, the GHG emission per kwh of the diesel engine power plant is $-0.6251 \mathrm{~kg} \mathrm{CO}{ }_{2}$ eq. $/ \mathrm{kwh}$. At $120 \mathrm{~km}$, the $\mathrm{GHG}$ emission per kwh is -0.6312 . The natural gas turbine power plant has less negative GHG emission compared to other power plants. At zero distance, the GHG emission per kwh is $-0.4869 \mathrm{~kg} \mathrm{CO}$ eq. per kwh. At $120 \mathrm{~km}$, the GHG emission per kwh is $-0.4822 \mathrm{~kg} \mathrm{CO}_{2}$ eq. per kwh. 


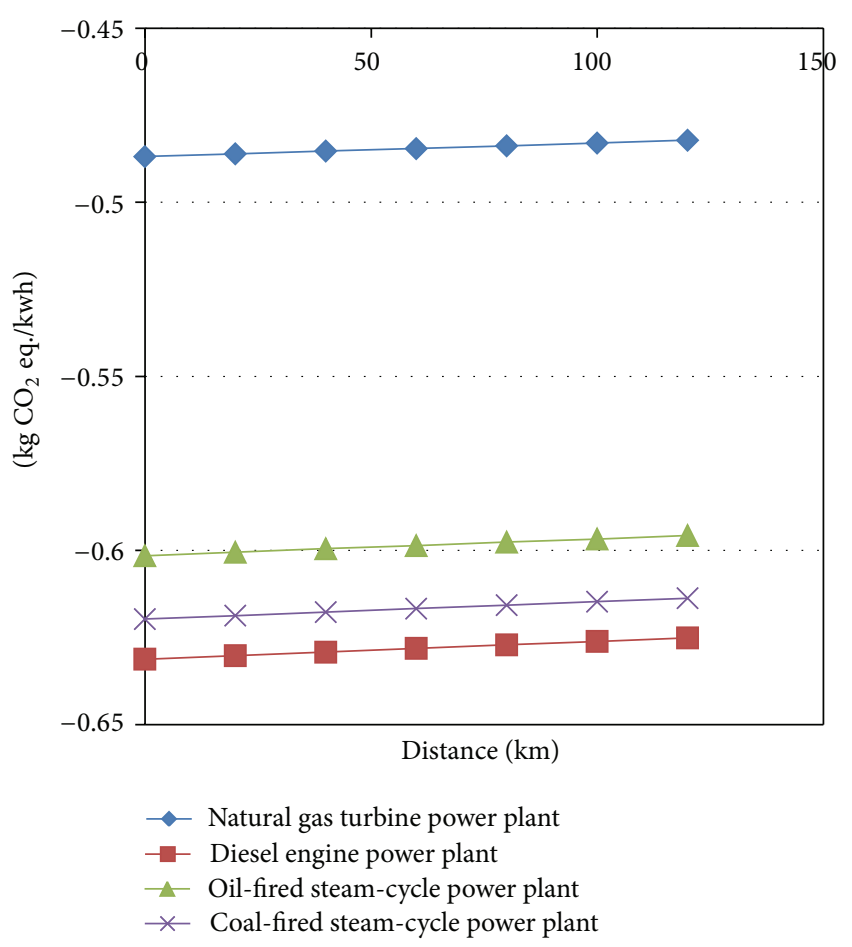

FIGURE 12: Dependence of total GHG emission on distance between pyrolysis plant and power plant $\left(\mathrm{kg} \mathrm{CO}_{2}\right.$ eq./kwh).

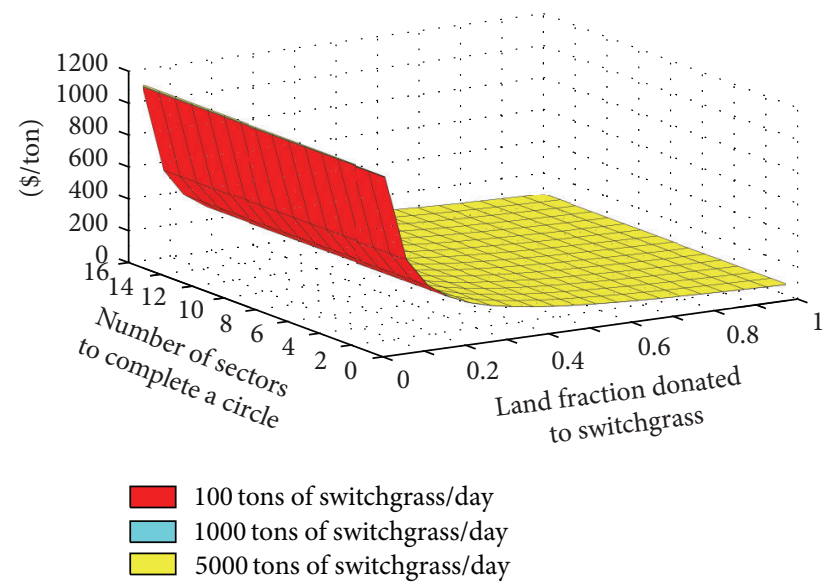

FIGURE 13: Dependency of switchgrass price on land fraction and field shape.

4.8. Land Fraction and Field Shape Effect. In this study, the land fraction and field shape effect has been analyzed. The land fraction and field shape have an effect on switchgrass price, pyrolysis oil price, electricity cost, and GHG emission per kwh. The field was divided into numbered sectors to complete a circle $(n)$. The $n=1$ represented a complete circles-like shape. The $n=10$ to 16 represented the long, narrow shapes of the divided sectors.

4.8.1. Land Fraction and Field Shape Effect on Switchgrass Price. From Figure 13, the land fraction used for switchgrass

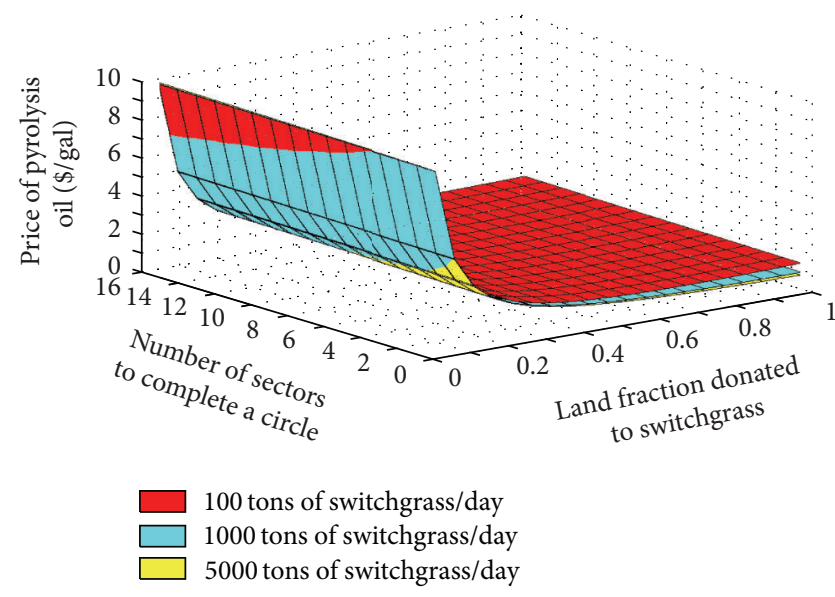

FIGURE 14: Dependency of pyrolysis oil price on land fraction and field shape.

and the number of sectors to complete a circle affect switchgrass price. The capacity of the pyrolysis plant has a small effect compared to the land fraction used for switchgrass. The capacity of the pyrolysis plant at 1000 tons per day is chosen as a representative of this calculation. If all the land is used for switchgrass (100\%) and the field shape is circular, the switchgrass price can reduce to $\$ 53.48$ per ton. From this information, the most important parameter is land fraction used for switchgrass. The switchgrass should be grown in an isolated empty field, separated from other plant species. This can lower the price of switchgrass.

4.8.2. Land Fraction and Field Shape Effect to Pyrolysis Price. From Figure 14, the land fraction used for switchgrass and number of sectors to complete a circle affect pyrolysis price. The capacity of the pyrolysis plant has some effects on the pyrolysis oil price. If pyrolysis plant capacity is 5,000 tons per day, pyrolysis oil price can be as low as $\$ 0.734$ per gallon if the land fraction used for switchgrass is 1 and the number of sectors to complete a circle which is 1 .

4.8.3. Land Fraction and Field Shape Effect Electricity Cost. In Figures 15, 16, 17, and 18, the land fraction utilized to grow switchgrass and the number of sectors to complete a circle affect pyrolysis price. The capacity of pyrolysis plant also has an effect on the pyrolysis price.

The coal-fired steam-cycle power plant produces the most expensive electricity cost per kwh. If pyrolysis plant capacity is 5000 tons per day, the electricity cost will be dropped to $\$ 0.102$ per kwh, when the entire land area is utilized to grow switchgrass (land fraction $=1$ ) and the field shape is circular $(n=1)$.

The natural gas turbine power plant produces the cheapest electricity cost per kwh. If pyrolysis plant capacity is 5000 tons per day, the electricity cost will be dropped to $\$ 0.077$ per $\mathrm{kwh}$, when the entire land area is utilized to grow switchgrass (land fraction $=1$ ) and the field is circular $(n=1)$.

The oil-fired steam-cycle power plant produces a cheaper electricity cost than the diesel engine power plant. Based on 
Electricity price for substituting pyrolysis oil in diesel engine power plant $(\$ / \mathrm{kwh})$

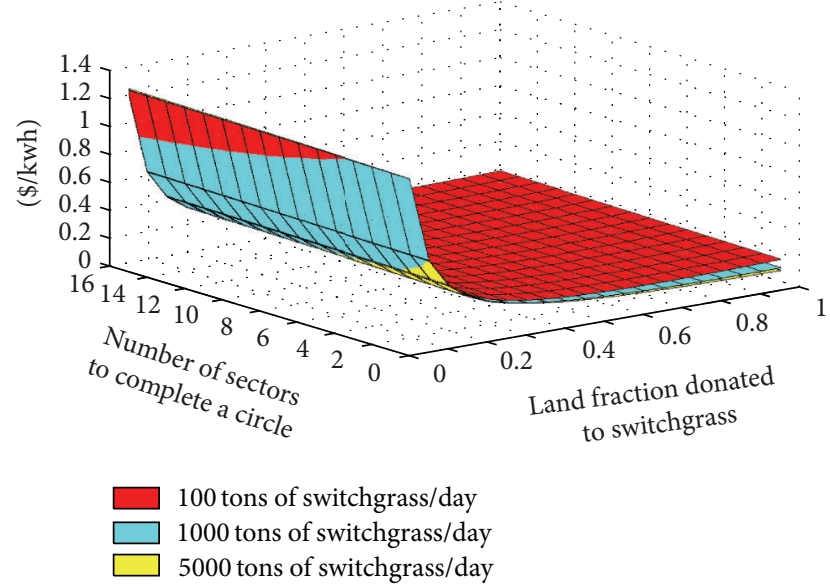

FIGURE 15: Electricity price for substituting pyrolysis oil in diesel engine power plant varies with land fraction and land shape.

Electricity price for substituting pyrolysis oil in natural gas turbine power plant $(\$ / \mathrm{kwh})$

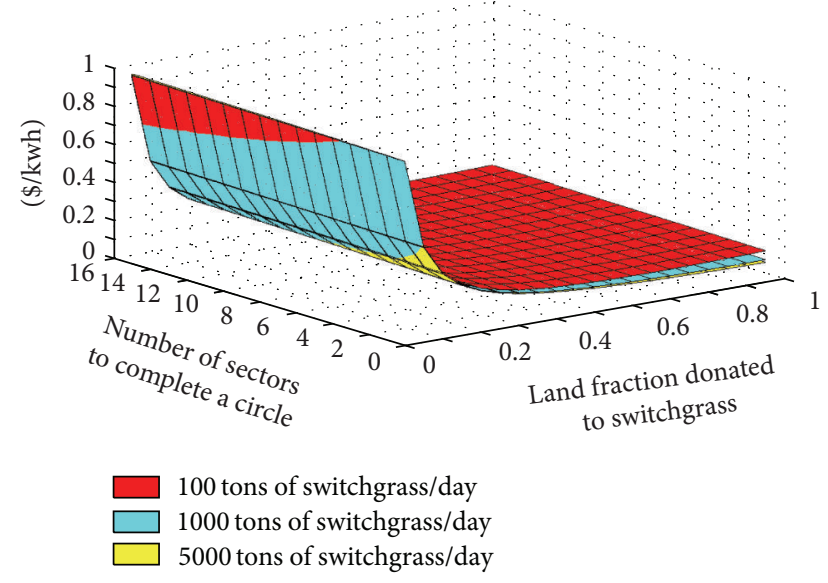

FIGURE 16: Electricity price for substituting pyrolysis oil in natural gas turbine power plant varies with land fraction and land shape.

this analysis, the natural gas turbine power plant is the most promising plant to utilize pyrolysis oil since it produces the cheapest electricity cost. The electricity cost at 7.70 cent per $\mathrm{kwh}$ is preferable since it is a competitive cost to conventional energy resources. According to the U.S. Energy Information Administration [59], the average electricity cost in the United States in 2011 was $\$ 0.10$ per $\mathrm{kwh}$. The electricity cost at 7.70 cent per kwh can be obtained only if the entire field is utilized to grow switchgrass. However, it is impossible to fill such a huge area $(441880 \mathrm{Ha})$ with a sea of switchgrass. The efficient management of growing, transportation, storage and pyrolysis, and choosing a suitable power plant are all required in order to make switchgrass energy sustainable and competitive with conventional energy sources.
Electricity price for substituting pyrolysis oil in oil-fired steam-cycle power plant ( $\$ / k w h)$

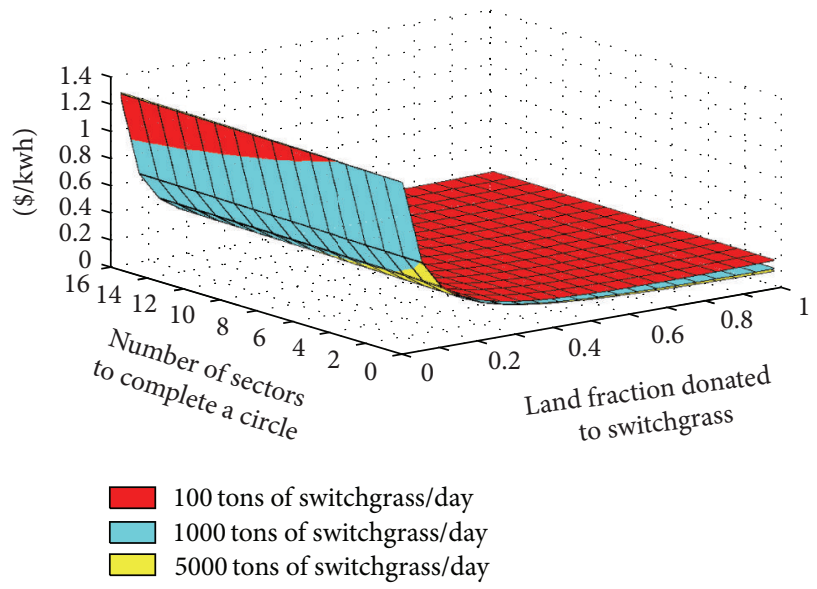

FIGURE 17: Electricity price for substituting pyrolysis oil in oil-fired steam-cycle power plant varies with land fraction and land shape.

Electricity price for substituting pyrolysis oil in coal-fired steam-cycle power plant $(\$ / \mathrm{kwh})$

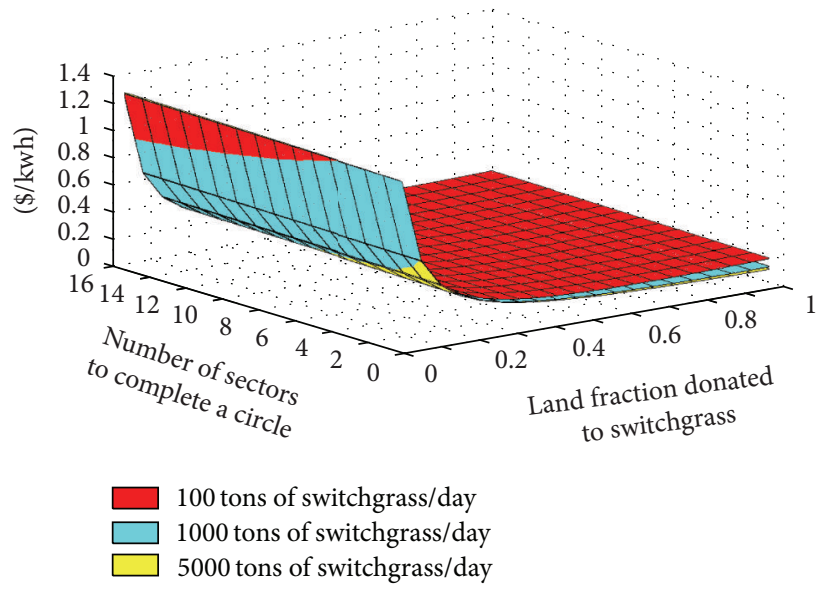

FIGURE 18: Electricity price for substituting pyrolysis oil in coal-fired steam-cycle power plant varies with land fraction and land shape.

4.8.4. Land Fraction and Field Shape Effect on the Total GHG Emission. Figures 19, 20, 21, and 22 show the GHG emission per kwh. The land fraction used for switchgrass, number of sectors to complete a circle, and type of power plant have effects on the GHG emission. The pyrolysis plant capacity has a small effect on the GHG emission. In Figures 19 to 22 , four power plants are shown. Operating all of the power plants with pyrolysis oil from switchgrass has negative GHG emissions. The most negative GHG emission per kwh comes from the diesel engine power plant. The least negative GHG emission per kwh comes from the natural gas turbine power plant.

For the diesel engine power plant, if all the land is used to grow switchgrass (land fraction $=1$ ) and the field is circular 
Total emission of switchgrass pyrolysis oil substituting in diesel engine power plant $\left(\mathrm{kg} \mathrm{CO}_{2} / \mathrm{kwh}\right)$

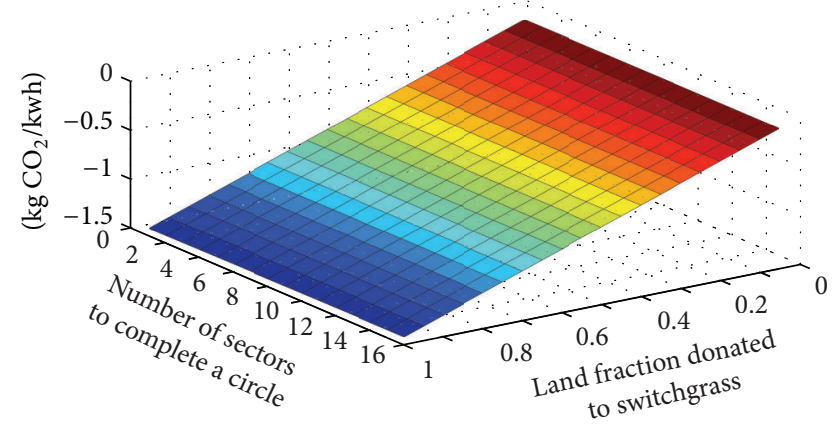

FIGURE 19: Total emission of switchgrass pyrolysis oil substituting in diesel engine power plant varies with land fraction and field shape.

Total emission of switchgrass pyrolysis oil substituting in natural gas turbine power plant $\left(\mathrm{kgCO}_{2} / \mathrm{kwh}\right)$

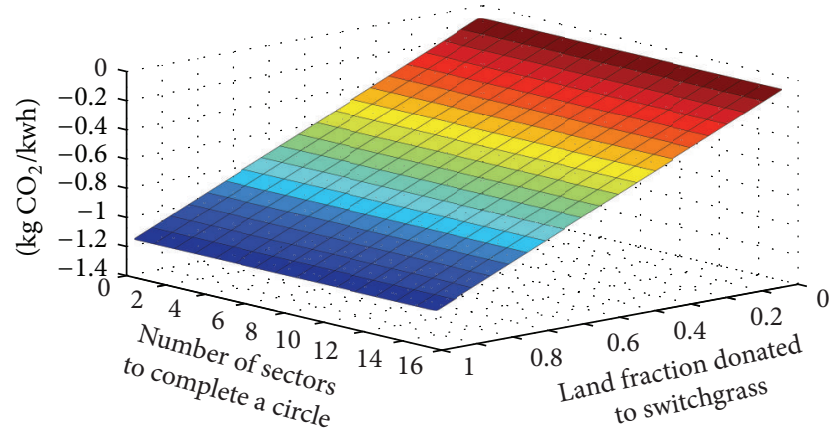

FIGURE 20: Total emission of switchgrass pyrolysis oil substituting in natural gas turbine power plant varies with land fraction and field shape.

$(n=1)$, the GHG emission is $-1.4321 \mathrm{~kg} \mathrm{CO}_{2}$ eq. per $\mathrm{kwh}-$ the lowest GHG emission.

For the natural gas turbine power plant, if all the land is used to grow switchgrass (land fraction $=1$ ) and the field is circular $(n=1)$, the GHG emission is $-1.1037 \mathrm{~kg} \mathrm{CO}_{2}$ eq. per kwh.

In this study, the land fraction used for switchgrass was the most important parameter for reducing GHG emissions. Comparing the GHG emission of pyrolysis oil from switchgrass to that of conventional fossil fuels (reported in Table 14), the GHG emission from pyrolysis oil was desired. All of the power plants that used pyrolysis oil from switchgrass were environmentally friendly since total GHG emission from the process was negative. Based on this analysis, the switchgrass field adsorbed more GHG than was emitted from other processes.

\section{Conclusion}

This study is based on biooil produced through fast pyrolysis. The switchgrass was grown in fields of different shapes and land fractions. life cycle assessment analysis and Life cycle
Total emission of switchgrass pyrolysis oil substituting in oil-fired steam-cycle power plant $\left(\mathrm{kgCO}_{2} / \mathrm{kwh}\right)$

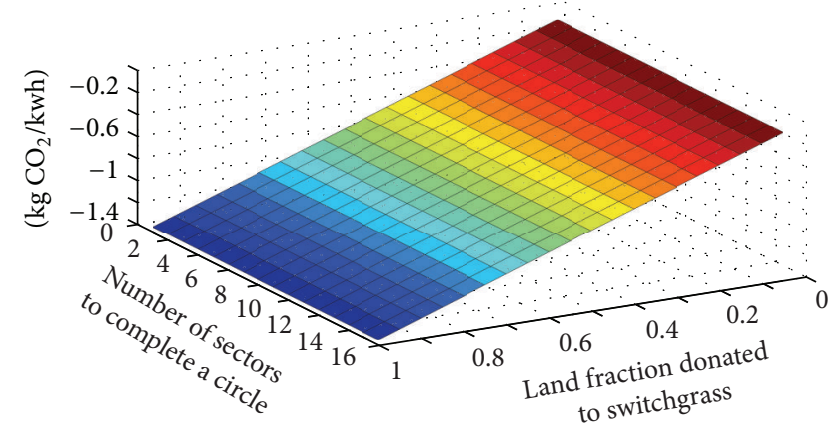

FIGURE 21: Total emission of switchgrass pyrolysis oil substituting in oil-fired steam-cycle power plant varies with land fraction and field shape.

Total emission of switchgrass pyrolysis oil substituting in oil-fired steam-cycle power plant $\left(\mathrm{kgCO}_{2} / \mathrm{kwh}\right)$

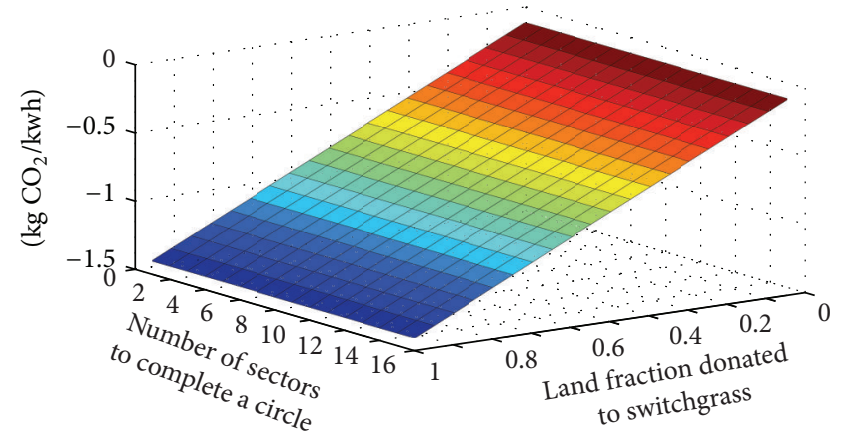

FIgURE 22: Total emission of switchgrass pyrolysis oil substituting in coal-fired steam-cycle power plant varies with land fraction and field shape.

TABLE 14: Life cycle assessment of greenhouse gas emissions (kt eq. $\mathrm{CO}_{2}$ per Twh) [47].

\begin{tabular}{lc}
\hline & $\begin{array}{c}\text { Low emission rate } \\
\text { kt CO }\end{array}$ \\
\hline eq. per TWh
\end{tabular}

cost analysis were performed on a system which consisted of cultivating and harvesting, transportation and storage, pyrolysis, transportation, and power generation. The GHG emission from the system was negative. Based on life cycle assessment, the power generation using pyrolysis oil is environmentally friendly since it reduces GHG emissions. On the other hand, life cycle cost analysis reveals that the electricity cost per kwh is higher than the conventional technology which uses fossil fuels. However, based on the analysis, the electricity cost from pyrolysis oil could be competitive if 
we can utilize the system with the cheapest scenarios. A circular field entirely filled with switchgrass is optimal for reducing electricity cost because of lower cost of cultivation, harvesting, and transport. A circular field with a pyrolysis plant capacity of 5000 tons per day using the natural gas turbine power plant could have an electricity cost as low as 7.70 cent/kwh. However, power generation from switchgrass requires a huge amount of land. We assumed that the land fraction utilized to grow switchgrass is the same as the average agriculture land fraction in the USA, which is $44.1 \%$. In order to provide enough switchgrass for a pyrolysis plant capacity of 5000 tons per day, a large land area size of 1706.11 square miles, which is even bigger than Rhode Island, is required. In the future, when carbon credit is fully utilized, pyrolysis oil could be more competitive for the benefit of carbon credit.

\section{References}

[1] IEA, Climate and Electricity Annual 2011, OECD Publishing, Paris, France, 2011.

[2] D. Y. Goswami, "A review and future prospects of renewable energy in the global energy system," in Proceedings of the ISES World Congress 2007 (Vol. I-Vol. V), D. Y. Goswami and Y. Zhao, Eds., pp. 3-10, Springer, 2008.

[3] A. Faaij, "Modern biomass conversion technologies," Mitigation and Adaptation Strategies for Global Change, vol. 11, no. 2, pp. 343-375, 2006.

[4] K. Roland, "Petroleum in the next century-conclusion: global warming is dire oil industry issue," The Oil and Gas Journal, vol. 96, no. 17, pp. 61-64, 1998.

[5] A. Richard, T. Berntsen, N. L. Bindoff et al., Climate Change 2007: The Physical Science Basis, Summary for Policy Makers, Agenda Collective, Paris, France, 2007.

[6] D. J. Hofmann, J. H. Butler, and P. P. Tans, "A new look at atmospheric carbon dioxide," Atmospheric Environment, vol. 43, no. 12, pp. 2084-2086, 2009.

[7] T. J. Hammons, "Impact of electric power generation on green house gas emissions in Europe: Russia, Greece, Italy and views of the EU power plant supply industry-a critical analysis," International Journal of Electrical Power and Energy Systems, vol. 28, no. 8, pp. 548-564, 2006.

[8] Administration EI, Administration USEI, A. E. Outlook et al., "AEO 2012 early release overview," Energy, vol. 2012, pp. 1-13, 2012.

[9] J. G. Brammer, M. Lauer, and A. V. Bridgwater, "Opportunities for biomass-derived "bio-oil" in European heat and power markets," Energy Policy, vol. 34, no. 17, pp. 2871-2880, 2006.

[10] J. Fan, T. N. Kalnes, M. Alward, J. Klinger, A. Sadehvandi, and D. R. Shonnard, "Life cycle assessment of electricity generation using fast pyrolysis bio-oil," Renewable Energy, vol. 36, no. 2, pp. 632-641, 2011.

[11] Y. Solantausta, N. Nylund, and S. Gust, "Use of pyrolysis oil in a test diesel engine to study the feasibility of a diesel power plant concept," Biomass and Bioenergy, vol. 7, pp. 297-306, 1994.

[12] I. M. Arbon, "Worldwide use of biomass in power generation and combined heat and power schemes," Proceedings of the Institution of Mechanical Engineers A, vol. 216, no. 1, pp. 41-57, 2002.

[13] D. Chiaramonti, A. Oasmaa, and Y. Solantausta, "Power generation using fast pyrolysis liquids from biomass," Renewable and Sustainable Energy Reviews, vol. 11, no. 6, pp. 1056-1086, 2007.
[14] S. Arbogast, D. Bellman, J. D. Paynter, and J. Wykowski, "Advanced bio-fuels from pyrolysis oil: the impact of economies of scale and use of existing logistic and processing capabilities," Fuel Processing Technology, vol. 104, pp. 121-127, 2012.

[15] A. A. Boateng, D. E. Daugaard, N. M. Goldberg, and K. B. Hicks, "Bench-scale fluidized-bed pyrolysis of switchgrass for bio-oil production," Industrial \& Engineering Chemistry Research, vol. 46, pp. 1891-1897, 2007.

[16] L. Rinehart, 2006, Switchgrass as a bioenergy crop. National Center for Appropriate Technology, http://attra.ncat.org/attrapub/PDF/switchgrass.pdf.

[17] K. David and A. J. Ragauskas, "Switchgrass as an energy crop for biofuel production: a review of its ligno-cellulosic chemical properties," Energy and Environmental Science, vol. 3, no. 9, pp. 1182-1190, 2010.

[18] G. K. Evanylo, A. O. Abaye, C. Dundas et al., "Herbaceous vegetation productivity, persistence, and metals uptake on a biosolids-amended mine soil," Journal of Environmental Quality, vol. 34, no. 5, pp. 1811-1819, 2005.

[19] S. B. McLaughlin and L. A. Kszos, "Development of switchgrass (Panicum virgatum) as a bioenergy feedstock in the United States," Biomass and Bioenergy, vol. 28, no. 6, pp. 515-535, 2005.

[20] M. A. Sanderson, P. R. Adler, A. A. Boateng, M. D. Casler, and G. Sarath, "Switchgrass as a biofuels feedstock in the USA," Canadian Journal of Plant Science, vol. 86, no. 5, pp. 1315-1325, 2006.

[21] R. Lemus, E. C. Brummer, K. J. Moore, N. E. Molstad, C. L. Burras, and M. F. Barker, "Biomass yield and quality of 20 switchgrass populations in southern Iowa, USA," Biomass and Bioenergy, vol. 23, no. 6, pp. 433-442, 2002.

[22] J. H. Fike, D. J. Parrish, D. D. Wolf et al., "Switchgrass production for the upper southeastern USA: influence of cultivar and cutting frequency on biomass yields," Biomass and Bioenergy, vol. 30, no. 3, pp. 207-213, 2006.

[23] Eco Smes, LCA definition according to SETAC.

[24] G. Rebitzer, T. Ekvall, R. Frischknecht et al., "Life cycle assessment, part 1: framework, goal and scope definition, inventory analysis, and applications," Environment International, vol. 30, no. 5, pp. 701-720, 2004.

[25] M. Finkbeiner, A. Inaba, R. B. H. Tan, K. Christiansen, and H. Klüppel, "The new international standards for life cycle assessment: ISO 14040 and ISO 14044," International Journal of Life Cycle Assessment, vol. 11, no. 2, pp. 80-85, 2006.

[26] D. Ravemark, "State of the art study of LCA and LCC tools," 2003.

[27] H. Barringer, "A life cycle cost summary," in Proceedings of the IEEE International Conference on Software Maintenance, pp. 110, September 2003.

[28] Y. Kawauchi and M. Rausand, Life Cycle Cost (LCC) Analysis in Oil and Chemical Process Industries, Toyo Engineering, Chiba, Japan, 1999.

[29] MATLAB, 2009.

[30] E. Costs, "Estimated costs for production, storage and transportation of switchgrass," Production, pp. 1-8, 2008.

[31] Machinery Cost Estimates: Harvesting. Farm Business Management, pp. 0-4, 2010.

[32] Machinery Cost Estimates: Forage Field Operations. Farm Business Management, pp. 0-4, 2010.

[33] T. N. Maraseni, G. Cockfield, and A. Apan, "A comparison of greenhouse gas emissions from inputs into farm enterprises 
in southeast Queensland, Australia," Journal of Environmental Science and Health A, vol. 42, no. 1, pp. 11-18, 2007.

[34] M. Duffy and V. Y. Nanhou, "Costs of producing switchgrass for biomass in southern Iowa," in Proceedings of the 5th National Symposium New Crops and New Uses Strength in Diversity, J. Janick and A. Whipkey, Eds., pp. 267-275, ASHS Press, 2002.

[35] E. C. Brummer, C. L. Burras, M. D. Duffy, and K. J. Moore, Switchgrass Production in Iowa: Economic Analysis, Soil Suitability, and Varietal Performance, Oak Ridge National Laboratory, Oak Ridge, Tenn, USA, 2002.

[36] M. M. Wright, R. C. Brown, and A. A. Boateng, "Distributed processing of biomass to bio-oil for subsequent production of Fischer-Tropsch liquids," Biofuels, Bioproducts and Biorefining, vol. 2, no. 3, pp. 229-238, 2008.

[37] R. P. Overend, "The average haul distance and transportation work factors for biomass delivered to a central plant," Biomass, vol. 2, no. 1, pp. 75-79, 1982.

[38] Brazil Green Freight Transport Report. 2011.

[39] K. Paustian, J. Antle, J. Sheehan, and E. Paul, Agriculture's Role in Greenhouse Gas Mitigation, Pew Center on Global Climate Change, 2006.

[40] R. A. Ney and J. L. Schnoor, Greenhouse Gas Emission Impacts of Substituting Switchgrass for Coal in Electric Generation: The Chariton Valley Biomass Project, Center for Global and Regional Environmental Research, Iowa City, Iowa, USA, 2002.

[41] F. Cherubini and G. Jungmeier, "LCA of a biorefinery concept producing bioethanol, bioenergy, and chemicals from switchgrass," The International Journal of Life Cycle Assessment, vol. 15, pp. 53-66, 2010.

[42] S. B. McLaughlin and M. E. Walsh, "Evaluating environmental consequences of producing herbaceous crops for bioenergy," Biomass and Bioenergy, vol. 14, no. 4, pp. 317-324, 1998.

[43] P. Jaramillo, A Life Cycle Comparison of Coal and Natural Gas for Electricity Generation and the Production of Transportation Fuels, Carnegie Mellon University, Pittsburgh, Pa, USA, 2007.

[44] GHGenius model.

[45] A. Oasmaa, C. Peacocke, S. Gust, D. Meier, and R. McLellan, "Norms and standards for pyrolysis liquids. End-user requirements and specifications," Energy and Fuels, vol. 19, no. 5, pp. 2155-2163, 2005.

[46] H. W. Beaty, Handbook of Electric Power Calculations, McGrawHill, New York, NY, USA, 2001.

[47] L. Gagnon, Comparing Power Generation Options, 2003.

[48] M. Balat, M. Balat, E. Kirtay, and H. Balat, "Main routes for the thermo-conversion of biomass into fuels and chemicals, part 1: pyrolysis systems," Energy Conversion and Management, vol. 50, no. 12, pp. 3147-3157, 2009.

[49] K. Yoshikawa, "R\&D (research and development) on distributed power generation from solid fuels," Energy, vol. 31, no. 10-11, pp. 1656-1665, 2006.

[50] Y. Solantausta, A. Bridgwater, and D. Beckman, "Feasibility of power production with pyrolysis and gasification systems," Biomass and Bioenergy, vol. 9, no. 1-5, pp. 257-269, 1995.

[51] B. M. Wagenaar, E. Gansekoele, J. Florijn et al., "Bio-oil as natural gas substitute in a $350 \mathrm{MW}$ power station," in Proceedings of the 2nd World Conference on Biomass for Energy, Industry and Climate Protection, pp. 10-14, 2004.

[52] G. R. Herdin, F. Gruber, D. Plohberger, and M. Wagner, "Experience with gas engines optimized for H2-rich fuels," in Proceedings of the 2003 Spring Technical Conference of the ASME
Internal Combustion Engine Division (ICES '03), ICES2003-596, pp. 679-690, May 2003.

[53] Restmac: Creating Markets For Renewable Energy Technologies EU RES Technology Marketing Campaign, European Biomass Industry Association, Brussels, Belgium.

[54] M. Schreiner, G. Kampichler, S. Krzack, and B. Meyer, "Thermodynamic modelling of co-firing coal and biomass pyrolysis gas in a power plant," Fuel Processing Technology, vol. 92, no. 4, pp. 787-792, 2011.

[55] S. Czernik and A. V. Bridgwater, "Overview of applications of biomass fast pyrolysis oil," Energy and Fuels, vol. 18, no. 2, pp. 590-598, 2004.

[56] The World Bank, Agricultural Land (\% of Land Area), The World Bank, 2009.

[57] X. Qin, T. Mohan, M. El-Halwagi, G. Cornforth, and B. A. McCarl, "Switchgrass as an alternate feedstock for power generation: an integrated environmental, energy and economic life-cycle assessment," Clean Technologies and Environmental Policy, vol. 8, no. 4, pp. 233-249, 2006.

[58] U. S. Energy Information Administration, Electric Power Monthly with Data for June 2012, 2012.

[59] U. S. Energy Information Administration, Electricity Explained Factors Affecting Electricity Price 2010. 

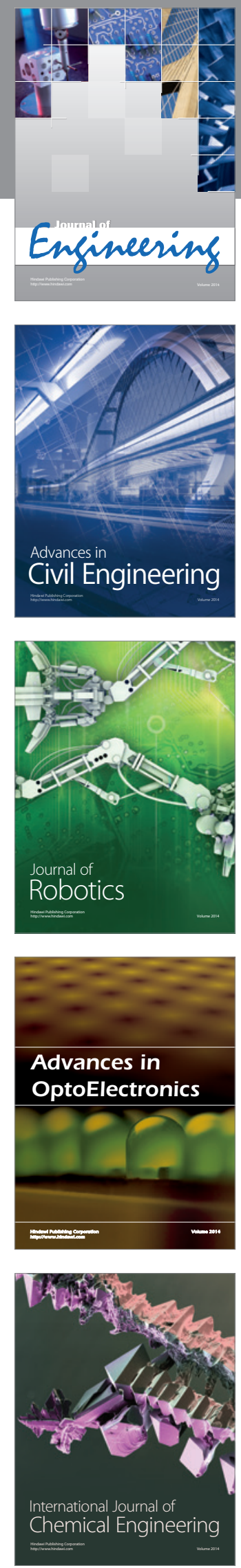

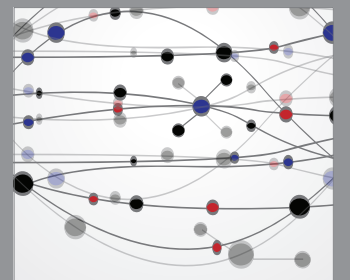

The Scientific World Journal
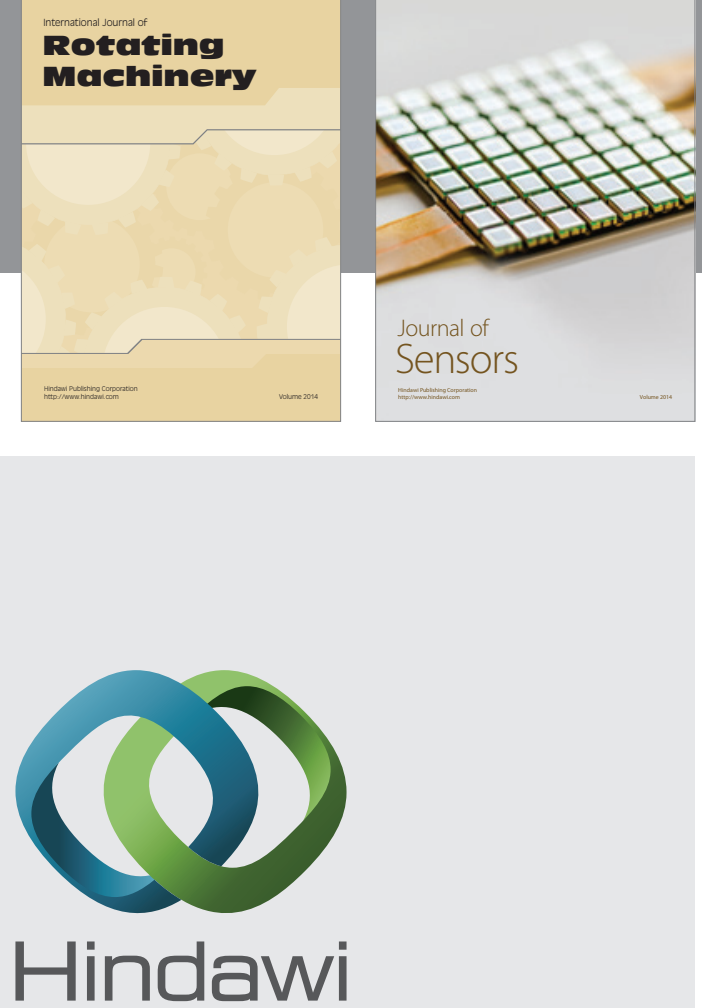

Submit your manuscripts at http://www.hindawi.com
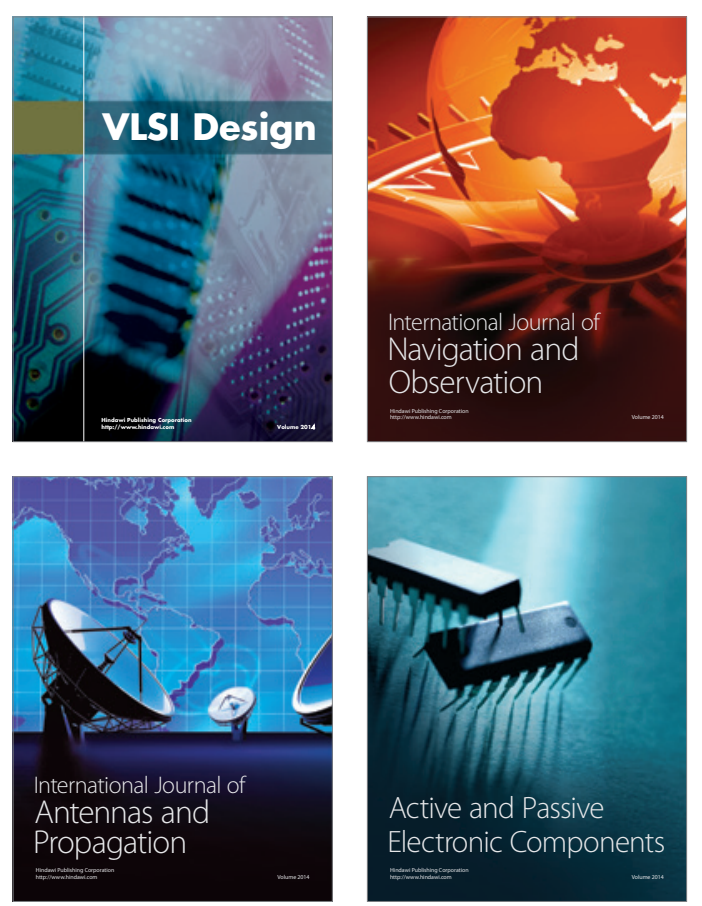
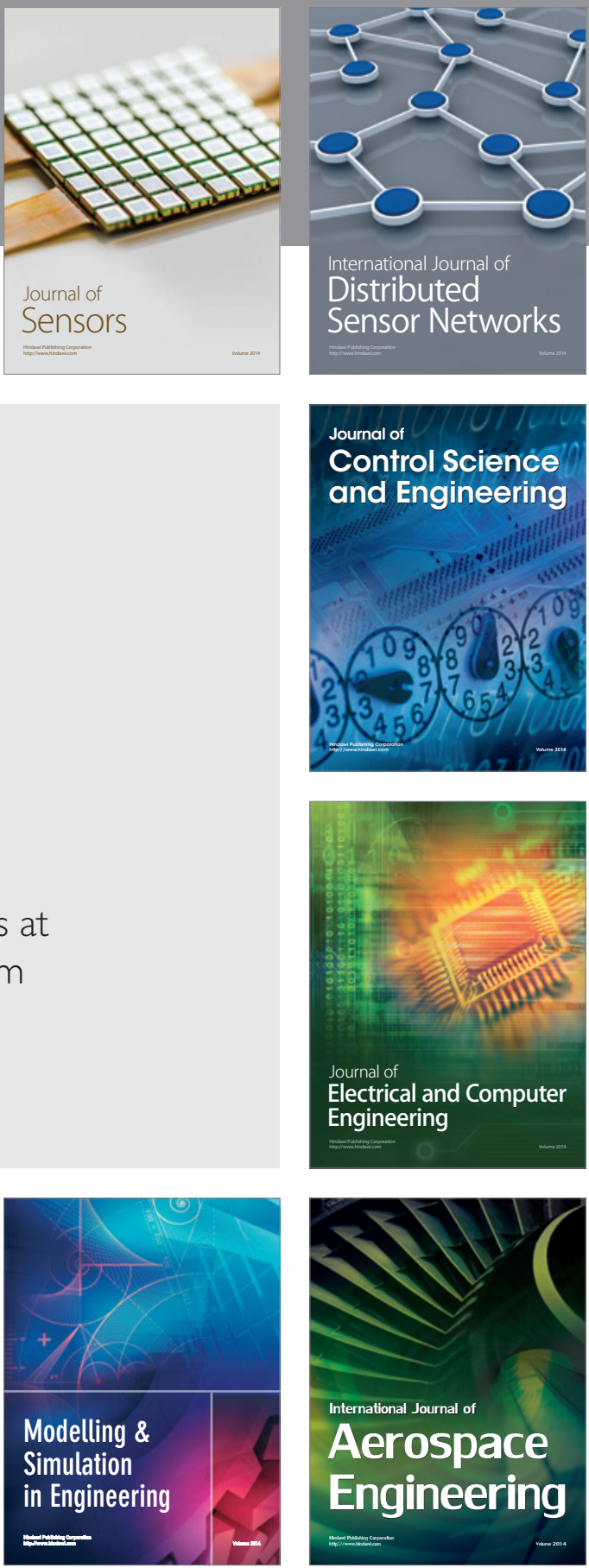

Journal of

Control Science

and Engineering
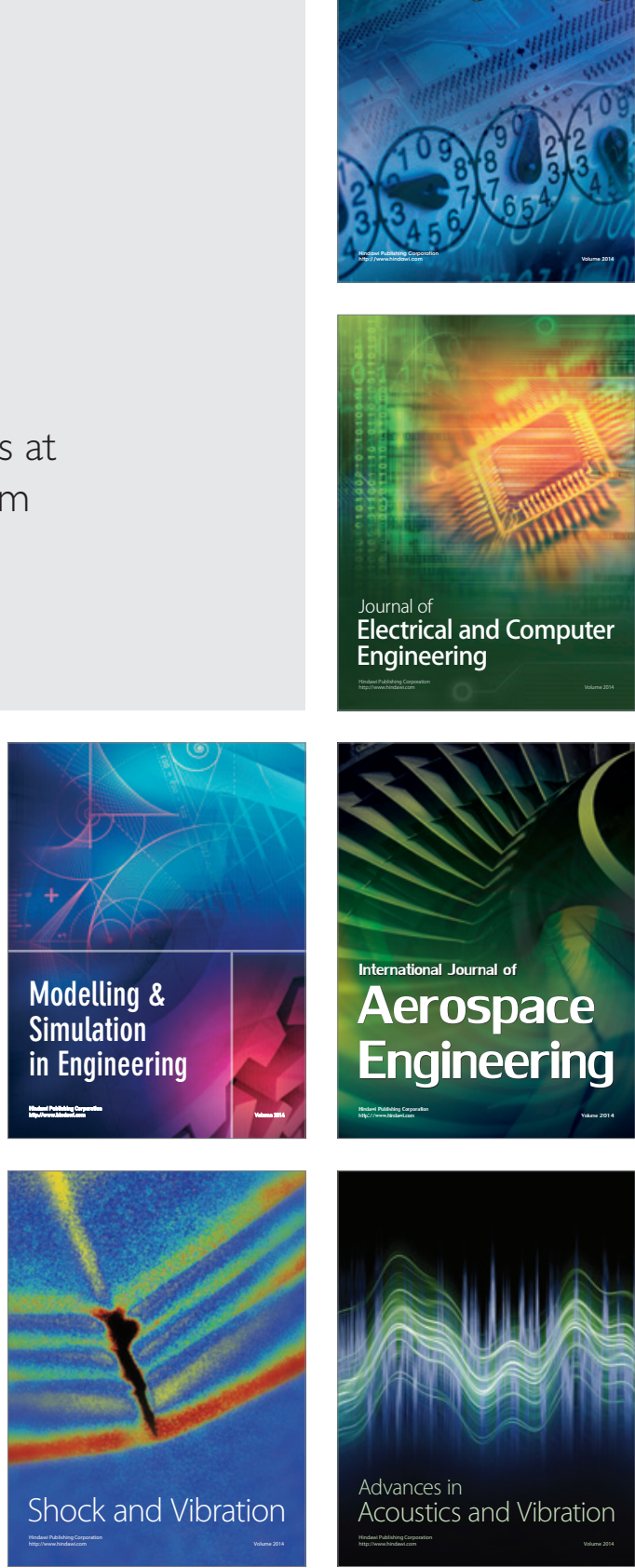